\title{
Producer Services, Manufacturing Linkages, and Trade
}

\author{
Joseph Francois • Julia Woerz
}

Received: 30 October 2007 / Revised: 18 January 2008 /

Accepted: 20 August 2008 / Published online: 4 October 2008

(C) The Author(s) 2008. This article is published with open access at Springerlink.com

\begin{abstract}
Working with a mix of panel data on goods and services trade for the OECD for 1994-2004, combined with social accounts data (i.e. data on intermediate linkages) for 78 countries benchmarked to the panel midpoint, we examine the role of services as inputs in manufacturing, with a particular focus on indirect exports of services through merchandise exports, and also on the related interaction between service sector openness and the overall pattern of manufacturing exports. From the cross-section, we also develop a set of stylized facts linking services to the level of development and the density of intermediate linkages. We find significant and strong positive effects from increased business service openness (i.e. greater levels of imports) on industries like machinery, motor vehicles, chemicals and electric equipment, supporting the notion that off-shoring of business services may promote the competitiveness of the most skill and technology intensive industries in the OECD. Conversely, we find evidence of negative general equilibrium effects for sectors that are less service intensive.
\end{abstract}

Keywords producer services · linkages · manufacturing exports $\cdot$ service imports · multiplier effects

JEL $\mathrm{F} 14 \cdot \mathrm{L} 8 \cdot \mathrm{O} 11$

Thanks are due for support from the World Bank for this project. Thanks are also due to seminar participants at the European Economic Associate meetings and the European Trade Study Group meetings. All errors are of course our own.

\section{J. Francois $(\bowtie)$}

Department of Economics, Johannes Kepler University Linz, Altenbergerstraße 69, 4040 Linz, Austria e-mail: joseph.francois@jku.at

J. Francois

Tinbergen Institute, Rotterdam, The Netherlands

J. Francois

CEPR, London, UK

J. Woerz

The Vienna Institute for International Economic Studies, Vienna, Austria 


\section{Introduction}

Merchandise trade dominates international trade, with about $70-80 \%$ of all cross-border transactions involving goods trade. Yet services dominate the domestic economic landscape in most middle- and high-income economies. At the same time, there is a growing realization that official trade data may actually underplay the role of services in trade, as they reflect neither the use of services as inputs for manufactured goods destined for export markets, nor the importance of services sold through local affiliates of multinationals. (See Hoekman 2006; Hoekman and Primo Braga 1997.)

In this paper we examine the role of services as inputs in manufactured exports, with a particular focus on indirect exports of services, and also on the related interaction between service sector openness and the relative performance of different sectors in the overall pattern of manufacturing performance. ${ }^{1}$ We provide cross-country and panel-based evidence to complement the case-study approach of the recent literature, while working with data that reflects the sweep of the information technology revolution across the service industries in the 1990s. Our data include a mix of panel data on goods and services trade for the 30 OECD Members for 1994-2004, combined with social accounts data (i.e. data on intermediate linkages) for 78 countries inclusive of our OECD sample and benchmarked to the year 2001 .

With increasing per capita income, we find an increasing demand for producer services as inputs in manufacturing production, especially so for the narrowly defined category of business services. We also find strong direct and indirect multiplier effects for producer services, again positively related to income levels. Having quantified the importance of services as upstream inputs in manufacturing production, we next turn to the interaction of trade in both goods and services on the economy. On the one hand we observe strong indirect exports of producer services embodied as inputs in manufacturing. This is true across our sample of 78 low-, middle- and high-income countries. The relative importance of services in the total activity content of exports is also significantly correlated with income levels. With increasing per capita income the service intensity of exports increases - especially so for business services. On the other hand, from panel regressions, we also find significant and strong positive effects from increased business service openness (implying greater trade and FDI flows) on industries like machinery, motor vehicles, chemicals and electric equipment. Conversely, we find evidence of negative general equilibrium effects for sectors that are less service intensive. This set of results on services and goods trade linkages supports the notion that off-shoring of business services does actually promote the competitiveness of the most skill and technology intensive industries in the OECD countries, with an impact similar to that of biased technical change. Finally, we find evidence that the importance of services as inputs in the post-industrial (high income OECD) economies has increased substantially, with the depth of intermediate linkages in modern service-based economies being greater than at the start of the 1990s.

We proceed as follows. In Section 2 we provide a short overview of the current literature, placing the present exercise in context. In Section 3 we then provide an overview of production and trade patterns, including the development of stylized facts. In Section 4 we then turn to panel regressions to examine trade-based linkages. We offer a brief summary and concluding remarks in Section 5.

\footnotetext{
${ }^{1}$ A related strand of the literature focuses not so much on production patterns linked to intermediate services trade and FDI, but on the corresponding shift in employment patterns and productivity that follows from trends in FDI and offshoring. (Feenstra and Hanson 1999, 2003; Bloningen 2005.)
} 


\section{Background}

Explanations for the now dominant role of services in modern economies, relative both to low-income countries and to historic patterns within OECD countries themselves, have generally emphasized demand-side factors. Clark (1940) was the first to note a rising share of services associated with economic growth and attributed this to demand side factors, while later Baumol et al. (1985) related the pattern of rising final or consumer service prices to relative productivity differentials and to a predicted stagnation of overall productivity growth. In general, this literature stressed final demand services and non-homothetic demand as the driving force in service sector growth. The message of Baumol, in particular, was that services would grow to be an ever-increasing drag on productivity growth in the OECD. Yet there have also been important post-War changes linked to intermediate or producer services. Working with national accounts data that largely pre-date the information technology revolution of the 1990s, Park (1989), Park and Chan (1989), and Uno (1989) have all confirmed the post-War rise in the importance of producer service inputs into manufacturing along the lines stressed by Katouzian (1970) and Francois (1990a). In contrast to the Baumol disease characterized by productivity slow-down, producer-service centered research points instead to service sector expansion linked to overall productivity growth rather than stagnation. (See Francois 1990a; Hoekman 2006.)

Well before the full impact of the information technology revolution was felt, Bhagwati $(1984 a, b)$ pointed out that the disintegration of production (a process he called "splintering") combined with increased trade in services was likely to lead in the future to what the recent empirical literature now calls offshoring. This has been confirmed by subsequent experience and the findings of the services offshoring literature. Recent literature along these lines includes Amiti and Wei (2005), Feenstra and Hanson (1996, 1999), Francois et al. (2004), Javorcik (2004), Markusen (2005), Markusen and Venables (1997), and Yeaple (2006).

\section{Data}

We work here with data covering trade in goods and services, and also data on intermediate linkages between goods sectors and services sectors from national accounts data for 78 countries. This requires combining data from a number of different sources. Our sectoring scheme is ultimately a compromise, limited by the structure of our national accounts data, and also by the constraints imposed by the breakdown of available service trade data. We employ a concordance so that services and goods trade data are defined at the same level of aggregation for which we also have corresponding data on intermediate use by manufacturing and service industries (upstream and downstream linkages). We define our basic data sources here, as well as some indexes derived from these data that are used in the sections that follow. ${ }^{2}$

We have a panel of trade data spanning from 1994-2004 for the 30 OECD Members, and a broader cross-section of social accounting data for 78 countries for the mid-point of the panel, year 2001. Data on services trade come from the OECD supplemented with published IMF balance of payments statistics. These data are based on balance of payment statistics and correspond mainly to what is known as GATS mode 1 - cross border tradeand mode 2-movement of consumers. Data are usually reported for total services trade

\footnotetext{
${ }^{2}$ The data, including the direct and indirect linkage indexes, are available on request.
} 
flows on a bilateral basis or for trade flows to the world broken down by sectors. EUROSTAT provides data on services trade flows on a dual breakdown, by partners and sectors at the same time for a limited number of countries. ${ }^{3}$ For our purposes, the sector breakdown is sufficient. In these data, information on detailed services trade by sector is limited to OECD Members. This gives us a range of national per-capita incomes spanning from Mexico to Switzerland, but leaves out the lower income countries. As such, while we will be working with national accounts data for countries covering the full range of low-, middle-, and high-income countries (basically from Malawi to Switzerland) in discussion of the 2001 cross-section, our panel analysis of trade data will by necessity be limited to the Mexico-to-Switzerland sub-sample of countries. Goods trade comes from the United Nations' COMTRADE database on commodity trade, aggregated to the sectors in our national accounts data (see below). Data on the national structure of production come from a set of input-output tables, organized in the form of social accounting matrices, for 78 countries for the year 2001. Of the 29 sectors, 15 are manufacturing sectors and 10 are service sectors (see Table 16 in the Appendix). We focus in particular on producer services, which are defined as the following: communication services, financial services, insurance services, business services and transportation services. ${ }^{4}$

We have organized our data as social accounting matrices (SAMs), meaning that we have a single entry bookkeeping representation of national income and receipts by sector and final consumers. Indexing the column by $i$ and the row by $j$, element $S_{i j}$ represents the expenditures from sector $j$ on inputs from sector $i$ (in the case of intermediate demand), or else it represents final consumption or external trade (imports and exports). (Reinert and Roland-Holst 1997; Bloningen et al. 1997). We also make use of a number of indexes derived from our SAMs. To examine production linkages, we begin by denoting a country's $\mathrm{n} \times \mathrm{n}$ social accounting matrix by $\mathbf{S}$ and a column unit $n$-vector by $\mathbf{e}$ (where $n$ is the number of elements in the column and row indexes.). Then $\mathbf{c}=\mathbf{e}^{\prime} \mathbf{S}$ is the column-sum vectors of $\mathbf{S}$. If $\mathrm{a}^{\wedge}$ over a vector is used to denote the corresponding $n$-dimensional diagonal matrix, then

$$
\mathbf{A}=\mathbf{S} \hat{\mathbf{c}}^{-1}
$$

Where A represents the column-sum normalized SAM. Hence, while $S_{i j}$ is the actual expenditure received by sector $i$ from sector $j$, an element $A_{i j}$ is the proportion of sector j's expenditure received by sector i. Working with the column-normalized A matrix, we examine correlations between cross-country per capita income levels and the basic density of the intermediate use matrix. Formally, we define the linkage index D as:

$$
D=\frac{\sum_{j \in \lambda} \sum_{i \in \lambda} A_{i j}}{\sum_{j \in \lambda} \sum_{i \in \omega} A_{i j}}
$$

where $\lambda$ is the set of industry accounts and $\omega$ is the set of industry plus value-added accounts. The index D measures the relative density of the column-normalized intermediate use matrix. It reflects the importance of backward linkages between sectors, relative to the total level of production activity in the economy.

\footnotetext{
${ }^{3}$ Eurostat covers 31 reporting countries - the EU25 plus Bulgaria, Japan, Norway, Romania, Turkey and the USA - and 64 partner countries over a total period of 10 to at most 20 years (1985-2004). Bilateral services trade flows are classified into 11 economic activities according to the BOP Manual 5 classification.

${ }^{4}$ For a discussion of source data see Dimaranan (2006).
} 
While the elements of the A matrix can be interpreted as direct input coefficients, we will also be interested in the complete set of linkages, involving both direct input demand (like services bought by the transport equipment sector), and also indirect linkages (such as the services bought by the steel sector which then is sold downstream to the transport equipment sector). (See Reinert and Roland-Holst 1994.) To do this, we divide the $n$ accounts of a country's SAM into two groups: $m$ endogenous accounts and $k$ exogenous accounts. Following convention, we define the $k$ exogenous accounts as the government, capital, and rest-of-world accounts (see Robinson, 1989). All remaining accounts, including the consumption account, are endogenous. Define the sub-matrix of $\mathbf{A}$ consisting of the $\mathrm{m}$ endogenous accounts as $\mathbf{A}_{\mathbf{m m}}$. The multiplier matrix is given by

$$
\mathbf{M}=\left(\mathbf{I}_{\mathbf{m}}-\mathbf{A}_{\mathbf{m m}}\right)^{-\mathbf{1}}
$$

A representative element of the $\mathbf{M}$ matrix, $M_{i j}$, gives the direct and indirect marginal effects on sector $i$ income (demand) caused by an exogenous unit increase in sector $j$ income (demand). Following Reinert and Roland-Holst, we take one final step and use the multiplier matrix to break down total exports into implied total direct and indirect demand. Define $f_{i}$ as the export final demand for commodity $i$, and $\mathbf{f}$ as the column vector of these elements. The coefficient $\phi$

$$
\phi_{i}=f_{i} / \mathbf{f}^{\prime} \mathbf{e}
$$

gives the share of commodity $i$ in total export demand, and the column vector $\Phi$ contains the full set of these coefficients. This vector represents direct export shares. To account for intermediate linkages, we also define the column vector

$$
\Omega=\mathbf{M} \Phi
$$

Elements $\omega_{i}$ of $\Omega$ give the weighted average direct and indirect effects on the value of activity in sector $i$ that follow from increasing export demand by one dollar, holding the sector composition of total exports constant.

\section{Services in production}

We start here with a focus on linkages between services and manufacturing. We make the following observations, based on patterns in the data as discussed in this section.

Observation 1: The importance of services in production rises in the cross-section with the level of development.

Observation 2: The density of intermediate linkages (defined below) exhibits an inverted U-pattern in the cross-section.

Observation 3: Service linkages to manufacturing have become increasingly important in the 1990s.

Observation 4: The rising importance of service linkages to manufacturing in the 1990s has shifted the turning point in the overall U-pattern in the density of intermediate linkages to a higher income level over the 1990s.

Building on patterns summarized in Observations 1 to 4 and explored econometrically in this section, in the next section we will then turn our attention to the implications of these basic patterns for the interaction between trade in goods and trade in services. 
From the earlier literature on the structure of production and demand across countries (Park 1989, Francois and Reinert 1996), we expect to see a rising demand for producer services for countries at higher levels of economic development. At the same time, from the corresponding literature on final demand (Hunter and Markusen 1989, Bhagwati 1984a,b, Panagariya 1988) we also expect a shift toward final service production driven by final demand factors. In employment and output terms, what results is a U-pattern, where the service sector in general shows an initial decline when a country shifts toward a more industrialized structure of production, and then starts to increase its share in the economy again as the country moves further towards a more modern, service-based economy. This overall pattern is driven by the interaction of final and intermediate demand factors. Our interest in this section is the intermediate demand factors driving demand for producer services. The role of services as inputs has important implications for the shift in the overall complexity of intermediate linkages between sectors linked to the level of development. At the same time, when we compare this pattern to the literature for earlier periods, it appears that the complexity of intermediate linkages (the overall "roundaboutness of production") has grown deeper over the 1990s for the higher-income service-based economies, a pattern consistent with a generally rising importance for services as inputs.

Figure 1 plots the demand for business services (measured as the share of intermediate demands) against per-capita GDP at purchasing power parities in 2001. In the figure we show the share of services used in individual manufacturing sectors (from our use coefficients $A_{i j}$ ). While no significant relationship (positive nor negative) between percapita income and the demand for total services can be identified, we do find a positive relationship for most industries when looking at producer services only. However, the patterns point toward significant differences across individual manufacturing industries. When restricting our attention to business services only (these are activities such as accounting, book-keeping, management consultancy services, operational leasing, legal services, advertising, etc.) as in Fig. 1 we find a strong positive correlation for all manufacturing sectors. We test for the strength of this correlation for different service categories with the simple cross-section OLS model, given in equation 6:

$$
A_{i j k}=\alpha_{i j}+\beta 1_{i j} p c G D P_{k}+\beta 2_{i j} p c G D P_{k}^{2}+\varepsilon_{i j k}
$$

In equation (6), $A_{i j k}$ are the intermediate use shares from the use matrix $\mathbf{A}$ for each country $k$ for use of intermediates of each manufacturing industry in 2001 , while $p c G D P_{k}$ is per-capita income level, measured at purchasing parities for each of the 78 countries in our sample (all variables are in logs). The results of these regressions are reported in Table 1. (In every individual case we decide between a linear and a quadratic specification, depending on which one gives a better fit to the data on the basis of Chi-squared specification test statistics). Table 1 reports the OLS regression results separately for each manufacturing industry using producer services as the dependent variable. What we identify is a significant correlation between income levels and service intensity-U-shaped and statistically significant at the 1\%-confidence level-for the following industries: food, textiles, clothing, leather, paper, coke, chemicals, and metals. These industries are mostly labor and resource intensive. With increasing per capita income, the use of services as inputs in industrial production of such more labor intensive industries first declines and at a more developed stage rises again. Thus, a significant relationship between rising per-capita income and the use of services in manufacturing production emerges clearly at the industrial sector level. 

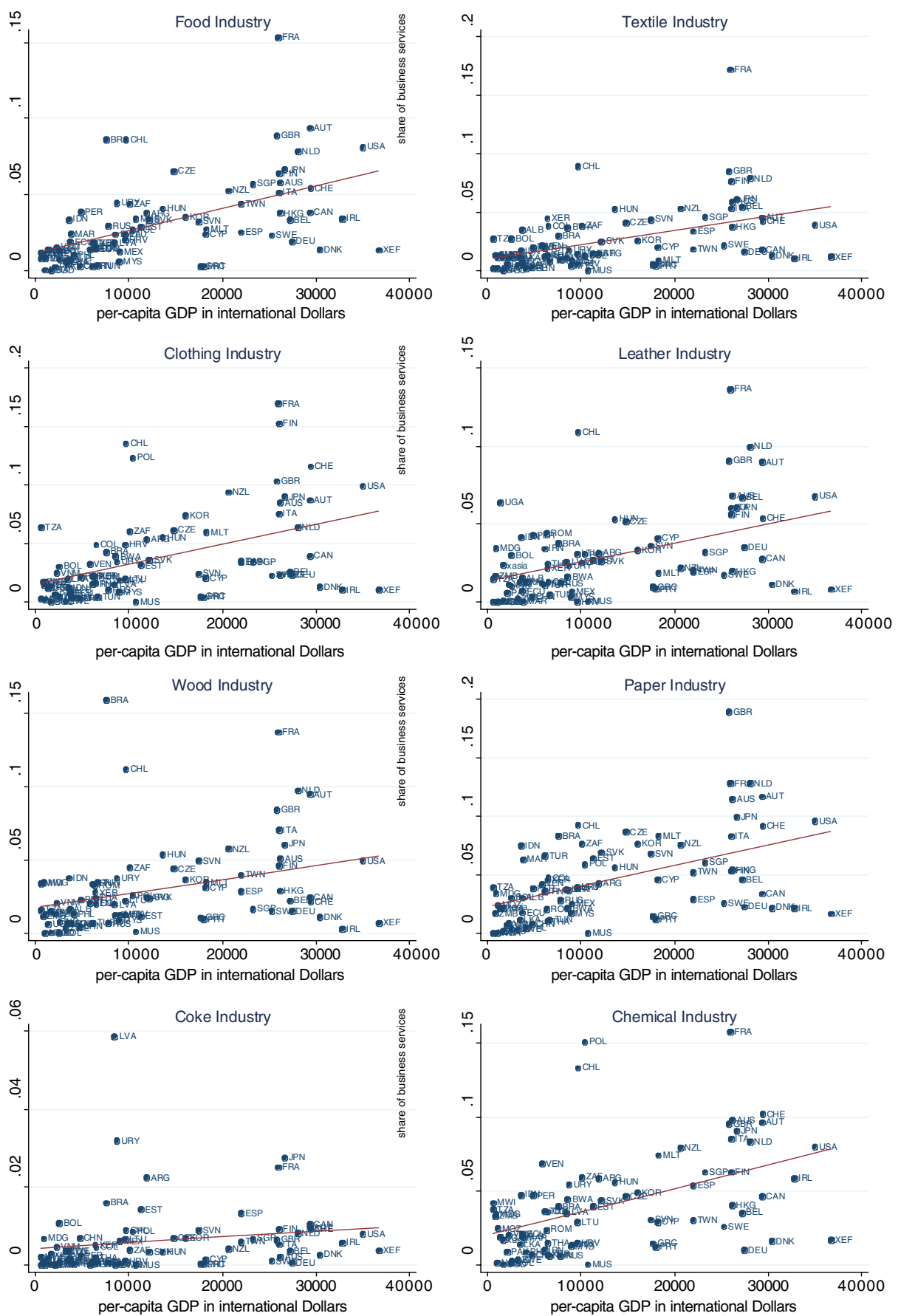

Fig. 1 Manufacturing demand for business services 

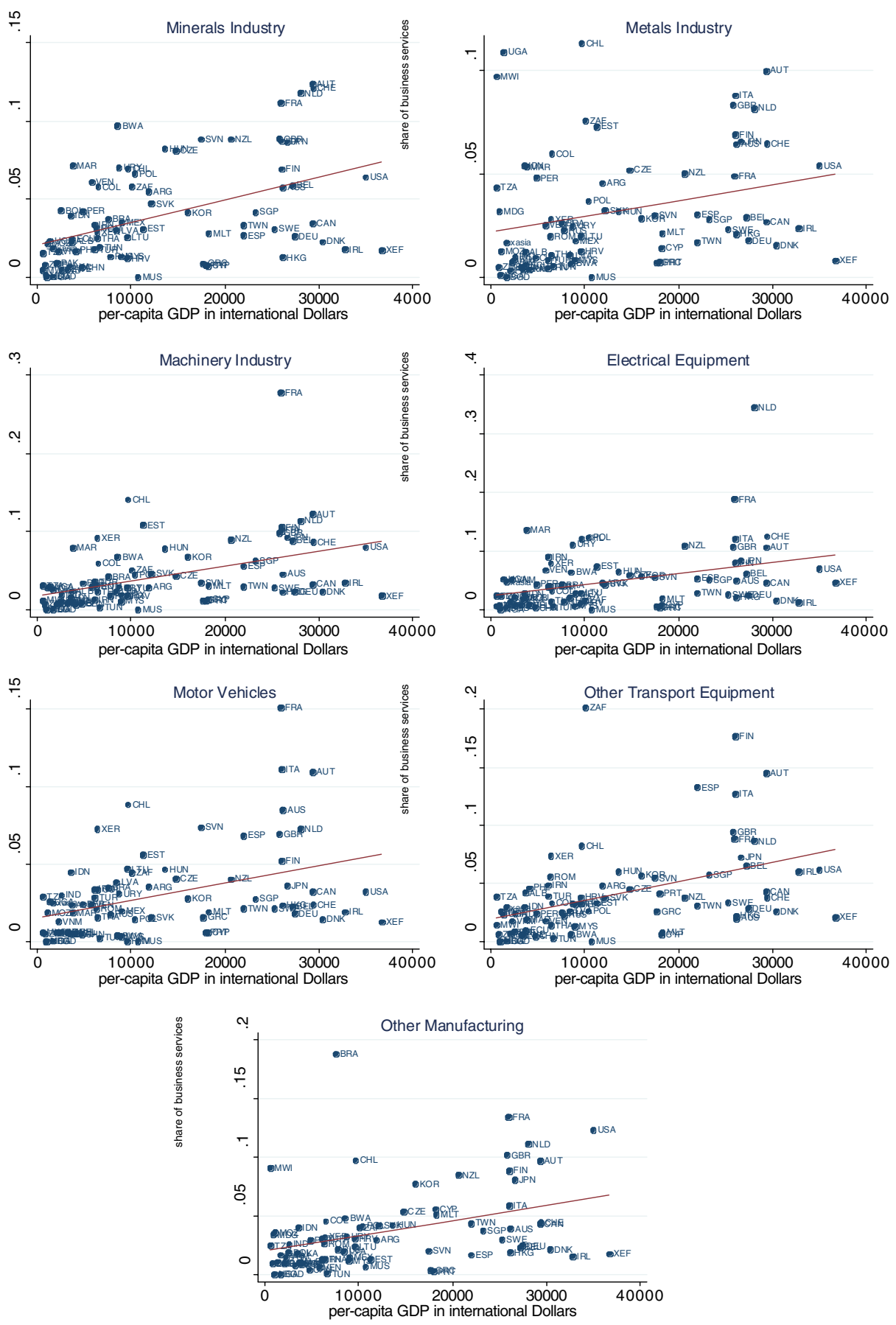

Fig. 1 (continued) 
Table 1 Manufacturing demand for producer services

\begin{tabular}{|c|c|c|c|c|c|}
\hline & GDP & $t$-stat & $\mathrm{GDP}^{2}$ & $t$-stat & $R^{2}$ \\
\hline Food & -3.14 & $-5.18^{\mathrm{a}}$ & 0.19 & $5.45^{\mathrm{a}}$ & 0.39 \\
\hline Textiles & -2.93 & $-2.20^{\mathrm{a}}$ & 0.17 & $2.30^{\mathrm{a}}$ & 0.07 \\
\hline Clothing & -2.98 & $-2.38^{\mathrm{a}}$ & 0.18 & $3.02^{\mathrm{a}}$ & 0.19 \\
\hline Leather & -3.91 & $-2.40^{\mathrm{a}}$ & 0.23 & $2.49^{\mathrm{a}}$ & 0.07 \\
\hline Wood & -1.21 & -1.20 & 0.07 & 1.29 & 0.03 \\
\hline Paper & -3.02 & $-3.23^{\mathrm{a}}$ & 0.18 & $3.39^{\mathrm{a}}$ & 0.16 \\
\hline Coke & -3.69 & $-2.11^{\mathrm{a}}$ & 0.20 & $2.04^{\mathrm{a}}$ & 0.10 \\
\hline Chemicals & -4.47 & $-4.86^{\mathrm{a}}$ & 0.27 & $5.02^{\mathrm{a}}$ & 0.21 \\
\hline Minerals & -0.64 & -0.54 & 0.04 & 0.68 & 0.07 \\
\hline Metals & -3.32 & $-3.39^{\mathrm{a}}$ & 0.19 & $3.38^{\mathrm{a}}$ & 0.10 \\
\hline Machinery & 0.27 & 0.18 & 0.00 & -0.01 & 0.13 \\
\hline Electrical equ. & 0.52 & 0.42 & -0.02 & -0.29 & 0.08 \\
\hline Motor vehicles & -0.88 & -0.93 & 0.05 & 1.00 & 0.03 \\
\hline Other transport equ. & -1.01 & -0.87 & 0.07 & 1.08 & 0.10 \\
\hline Other manufacturing & -1.99 & -1.42 & 0.13 & $1.65^{\mathrm{b}}$ & 0.10 \\
\hline
\end{tabular}

Dep. Var. is share of producer services in resp. industry; robust std. errors

${ }^{a}$ Indicates significance at $1 \%$ level

${ }^{\mathrm{b}}$ Indicates significance at $5 \%$ level

Table 2 reports the results for business services. Here, a highly significant linear relationship fits best in all industries, indicating a strong shift toward business service inputs in more developed countries. This underlines the increasing outsourcing of such activities to service firms (aka splintering and outsourcing). Whether these are sourced locally or imported from abroad cannot be assessed from this data, though Francois (1990a,

Table 2 Manufacturing demand for business services

\begin{tabular}{|c|c|c|c|}
\hline & GDP & $t$-stat & $R^{2}$ \\
\hline Food & 0.63 & $5.13^{\mathrm{a}}$ & 0.34 \\
\hline Textiles & 0.50 & $3.92^{\mathrm{a}}$ & 0.17 \\
\hline Clothing & 0.58 & $3.93^{\mathrm{a}}$ & 0.20 \\
\hline Leather & 0.40 & $2.88^{\mathrm{a}}$ & 0.12 \\
\hline Wood & 0.39 & $2.79^{\mathrm{a}}$ & 0.12 \\
\hline Paper & 0.59 & $3.14^{\mathrm{a}}$ & 0.21 \\
\hline Coke & 0.64 & $3.17^{\mathrm{a}}$ & 0.17 \\
\hline Chemicals & 0.47 & $3.39^{\mathrm{a}}$ & 0.18 \\
\hline Minerals & 0.52 & $4.87^{\mathrm{a}}$ & 0.30 \\
\hline Metals & 0.37 & $2.29^{\mathrm{a}}$ & 0.10 \\
\hline Machinery & 0.57 & $4.21^{\mathrm{a}}$ & 0.30 \\
\hline Electrical equ. & 0.40 & $4.16^{\mathrm{a}}$ & 0.17 \\
\hline Motor vehicles & 0.42 & $3.73^{\mathrm{a}}$ & 0.29 \\
\hline Other transport equ. & 0.46 & $4.07^{\mathrm{a}}$ & 0.32 \\
\hline Other manufacturing & 0.34 & $2.56^{\mathrm{a}}$ & 0.12 \\
\hline
\end{tabular}

Dep. Var. is share of business services in resp. industry; robust std. errors

${ }^{a}$ Indicates significance at $1 \%$ level 
b) and Francois and Reinert (1996) offer evidence that this involves both off-shoring and a real qualitative shift toward greater service intensity in the manufacturing sector.

Tables 3, 4, 5, 6 give comparable results for other producer services, such as communication services, financial services, insurance services and transportation services. The latter activity is usually not counted as a producer service. However, the increasing fragmentation of production also brings about a delocalization of production units. As a consequence, transportation services should also play an increasing role in modern service based economies. We find a U-shaped relationship between the use of services in production and stage of development in several of the sectors, especially so for financial and insurance services in the more labor and resource intensive industries.

We turn next to the overall density of the intermediate use matrix, or what is also known as the increasing roundaboutness of production. Services play an important role here (Francois 1990a,b, Arnold et al. 2006), while from earlier cross-country comparisons of input-output structures (Park and Chan 1989, Francois and Reinert 1996) we know that services exhibit fewer inter-industry linkages overall than manufacturing. What this implies is an overall shift in the density of the intermediate use matrix, with an initial rise from low to middle income economies (or from primary to manufacturing) and a subsequent drop with the move to higher income economies (or from manufacturing to service based).

Figure 2 plots the density index D as defined in equation (2) against per-capita income levels. The non-linear relationship between stage of development and the density of the intermediate use matrix becomes apparent, especially after removing two outliers, namely Bulgaria (with an apparent very high density at low per-capita income) and Luxembourg (again with a high density at an extremely high level of per-capita income). However, compared to the evidence for 1992 with a broadly comparable set of data presented in Francois and Reinert, the peak point with the highest density has shifted from approximately 12,000 USD per-capita income to 20,000 USD per-capita income by 2001

Table 3 Manufacturing demand for communication services

\begin{tabular}{|c|c|c|c|c|c|}
\hline & GDP & $t$-stat & $\mathrm{GDP}^{2}$ & $t$-stat & $R^{2}$ \\
\hline Food & 0.23 & $2.07^{\mathrm{a}}$ & & & 0.07 \\
\hline Textiles & 0.21 & $2.16^{\mathrm{a}}$ & & & 0.05 \\
\hline Clothing & 0.29 & $2.41^{\mathrm{a}}$ & & & 0.09 \\
\hline Leather & 0.11 & 0.91 & & & 0.01 \\
\hline Wood & 0.24 & $1.83^{\mathrm{b}}$ & & & 0.09 \\
\hline Paper & -2.98 & $-2.25^{\mathrm{a}}$ & 0.19 & $2.46^{\mathrm{a}}$ & 0.16 \\
\hline Coke & 0.25 & 1.18 & & & 0.02 \\
\hline Chemicals & 0.17 & 1.47 & & & 0.04 \\
\hline Minerals & 0.11 & 0.91 & & & 0.02 \\
\hline Metals & -2.79 & $-2.14^{\mathrm{a}}$ & 0.16 & $2.19^{\mathrm{a}}$ & 0.06 \\
\hline Machinery & 0.18 & $1.75^{\mathrm{b}}$ & & & 0.05 \\
\hline Electrical equ. & -0.11 & -1.20 & & & 0.02 \\
\hline Motor vehicles & -0.02 & -0.20 & & & 0.00 \\
\hline Other transport equ. & 0.13 & 1.08 & & & 0.03 \\
\hline Other Manufacturing & 0.05 & 0.64 & & & 0.00 \\
\hline
\end{tabular}

Dep. Var. is share of communication services in resp. industry; robust std. errors

${ }^{a}$ Indicates significance at $1 \%$ levels

${ }^{\mathrm{b}}$ Indicates significance at $5 \%$ levels 
Table 4 Manufacturing demand for financial services

\begin{tabular}{|c|c|c|c|c|c|}
\hline & GDP & $t$-stat & $\mathrm{GDP}^{2}$ & $t$-stat & $R^{2}$ \\
\hline Food & -6.77 & $-3.58^{\mathrm{a}}$ & 0.39 & $3.55^{\mathrm{a}}$ & 0.11 \\
\hline Textiles & -4.67 & $-2.79^{\mathrm{a}}$ & 0.27 & $2.76^{\mathrm{a}}$ & 0.08 \\
\hline Clothing & -6.79 & $-3.87^{\mathrm{a}}$ & 0.39 & $3.88^{\mathrm{a}}$ & 0.14 \\
\hline Leather & -4.05 & $-2.73^{\mathrm{a}}$ & 0.23 & $2.67^{\mathrm{a}}$ & 0.07 \\
\hline Wood & -3.09 & $-1.89^{\mathrm{b}}$ & 0.18 & $1.90^{\mathrm{b}}$ & 0.04 \\
\hline Paper & -6.74 & $-3.81^{\mathrm{a}}$ & 0.38 & $3.70^{\mathrm{a}}$ & 0.14 \\
\hline Coke & -7.57 & $-2.31^{\mathrm{a}}$ & 0.43 & $2.30^{\mathrm{a}}$ & 0.09 \\
\hline Chemicals & -6.49 & $-3.34^{\mathrm{a}}$ & 0.38 & $3.34^{\mathrm{a}}$ & 0.11 \\
\hline Minerals & -3.94 & $-2.17^{\mathrm{a}}$ & 0.23 & $2.16^{\mathrm{a}}$ & 0.05 \\
\hline Metals & -5.59 & $-3.06^{\mathrm{a}}$ & 0.32 & $2.99^{\mathrm{a}}$ & 0.09 \\
\hline Machinery & -2.35 & -1.25 & 0.14 & 1.33 & 0.03 \\
\hline Electrical equ. & -1.68 & -1.25 & 0.10 & 1.27 & 0.02 \\
\hline Motor vehicles & 0.59 & 0.36 & -0.04 & -0.40 & 0.01 \\
\hline Other transport equ. & -1.27 & -0.82 & 0.07 & 0.82 & 0.01 \\
\hline Other manufacturing & -6.76 & $-4.03^{\mathrm{a}}$ & 0.39 & $4.00^{\mathrm{a}}$ & 0.12 \\
\hline
\end{tabular}

Dep. Var. is share of financial services in resp. industry; robust std. errors

${ }^{a}$ Indicates significance at $1 \%$ level

${ }^{\mathrm{b}}$ Indicates significance at $5 \%$ level

measured at current prices. This corresponds to a shift from 16,860 USD to 20,000 USD in 2001 USD and thus means a real increase in the turning point. It is broadly consistent with the perception that the 1990s have seen a growth in the importance of services as inputs, driven in part by information technology. Such a shift offsets the drop in the intensity of

Table 5 Manufacturing demand for insurance services

\begin{tabular}{|c|c|c|c|c|c|}
\hline & GDP & $t$-stat & $\mathrm{GDP}^{2}$ & $t$-stat & $R^{2}$ \\
\hline Food & -4.54 & $-3.7^{\mathrm{a}}$ & 0.27 & $3.76^{\mathrm{a}}$ & 0.13 \\
\hline Textiles & -2.67 & $-1.7^{\mathrm{b}}$ & 0.15 & $1.71^{\mathrm{b}}$ & 0.04 \\
\hline Clothing & -3.71 & $-2.24^{\mathrm{a}}$ & 0.22 & $2.29^{\mathrm{a}}$ & 0.06 \\
\hline Leather & -3.25 & $-2.16^{\mathrm{a}}$ & 0.18 & $2.07^{\mathrm{a}}$ & 0.05 \\
\hline Wood & -2.24 & -1.31 & 0.14 & 1.40 & 0.04 \\
\hline Paper & -4.76 & $-3.37^{\mathrm{a}}$ & 0.27 & $3.32^{\mathrm{a}}$ & 0.13 \\
\hline Coke & 0.11 & 0.04 & -0.01 & -0.07 & 0.00 \\
\hline Chemicals & -4.99 & $-3.27^{\mathrm{a}}$ & 0.29 & $3.28^{\mathrm{a}}$ & 0.13 \\
\hline Minerals & -1.76 & -1.12 & 0.11 & 1.20 & 0.03 \\
\hline Metals & -3.53 & $-2.39^{\mathrm{a}}$ & 0.21 & $2.44^{\mathrm{a}}$ & 0.06 \\
\hline Machinery & -2.31 & -1.49 & 0.14 & 1.54 & 0.03 \\
\hline Electrical equ. & -0.54 & -0.33 & 0.03 & 0.33 & 0.00 \\
\hline Motor vehicles & -1.34 & -0.77 & 0.08 & 0.81 & 0.01 \\
\hline Other transport equ. & -2.92 & $-1.83^{\mathrm{b}}$ & 0.18 & $1.96^{\mathrm{a}}$ & 0.09 \\
\hline Other Manufacturing & -4.18 & $-3.21^{\mathrm{a}}$ & 0.24 & $3.25^{\mathrm{a}}$ & 0.11 \\
\hline
\end{tabular}

Dep. Var. is share of insurance services in resp. industry; robust std. errors

${ }^{a}$ Indicates significance at $1 \%$ level

${ }^{\mathrm{b}}$ Indicates significance at $5 \%$ level 
Table 6 Manufacturing demand for transportation services

\begin{tabular}{|c|c|c|c|c|c|}
\hline & GDP & $t$-stat & $\mathrm{GDP}^{2}$ & $t$-stat & $R^{2}$ \\
\hline Food & -2.63 & $-3.13^{\mathrm{a}}$ & 0.16 & $3.14^{\mathrm{a}}$ & 0.10 \\
\hline Textiles & -0.84 & -0.56 & 0.05 & 0.61 & 0.01 \\
\hline Clothing & -0.39 & -0.32 & 0.02 & 0.35 & 0.00 \\
\hline Leather & -1.82 & -1.06 & 0.10 & 1.06 & 0.02 \\
\hline Wood & 1.23 & 0.97 & -0.07 & -0.92 & 0.03 \\
\hline Paper & 0.17 & $1.79^{\mathrm{b}}$ & & & 0.07 \\
\hline Coke & -0.29 & $-2.22^{\mathrm{a}}$ & & & 0.06 \\
\hline Chemicals & -4.21 & $-4.09^{\mathrm{a}}$ & 0.24 & $4.08^{\mathrm{a}}$ & 0.13 \\
\hline Minerals & -0.67 & -0.53 & 0.04 & 0.59 & 0.01 \\
\hline Metals & -2.04 & -1.45 & 0.11 & 1.44 & 0.03 \\
\hline Machinery & 1.17 & 0.77 & -0.07 & -0.79 & 0.01 \\
\hline Electrical equ. & -0.16 & $-1.87^{\mathrm{b}}$ & & & 0.06 \\
\hline Motor vehicles & -0.83 & -0.65 & 0.04 & 0.59 & 0.02 \\
\hline Other transport equ. & -0.98 & -0.79 & 0.06 & 0.78 & 0.01 \\
\hline Other Manufacturing & -0.93 & -0.58 & 0.05 & 0.61 & 0.00 \\
\hline
\end{tabular}

Dep. Var. is share of transportation services in resp. industry; robust std. errors

${ }^{a}$ Indicates significance at $1 \%$ level

${ }^{\mathrm{b}}$ Indicates significance at $5 \%$ level

linkages in the high income, service-based economies that follows a shift from manufacturing to services.

We next look at the combination of direct and indirect effects for services generated by additional output demand in manufacturing sectors. In a first step, we simply group the multipliers $\omega$ from equation (5) by three types of manufacturing sectors, as shown in Fig. 3, and report them for five income groups (see Table 16 in the Appendix for the grouping of industries and countries). There are apparent differences between the effects generated by more skill and technology intensive industries as opposed to more labor and resource intensive industries. The labor intensive industries (food, textiles, clothing, leather and other transport equipment) involve lower multiplier effects in higher income countries. Further,

Fig. 2 Interindustry linkages

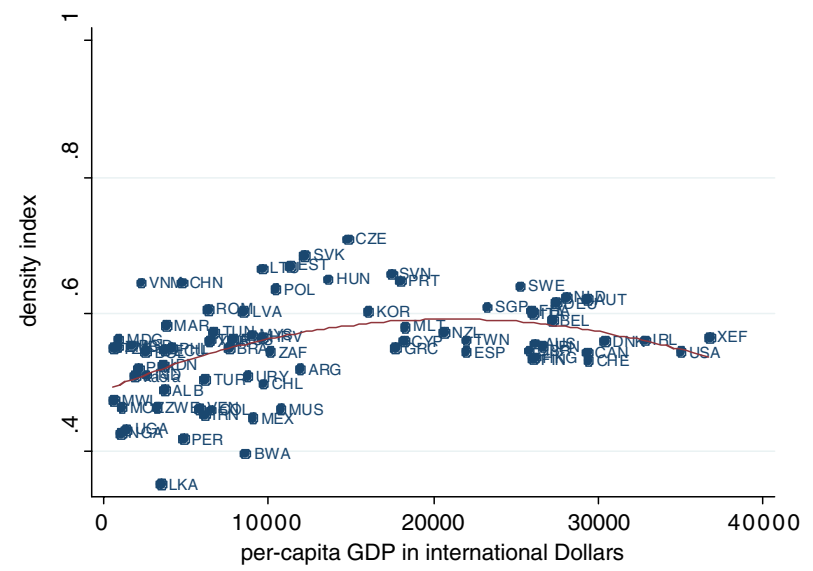




\section{Technology Intensive Industries}

$\square$ low income

$\square$ middle-low inc.

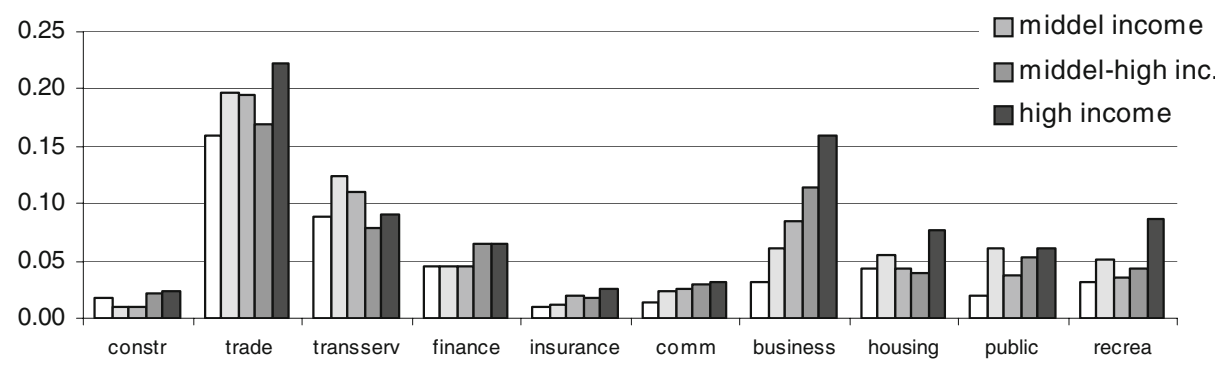

Resource Intensive Industries

口low income

口middle-low inc.

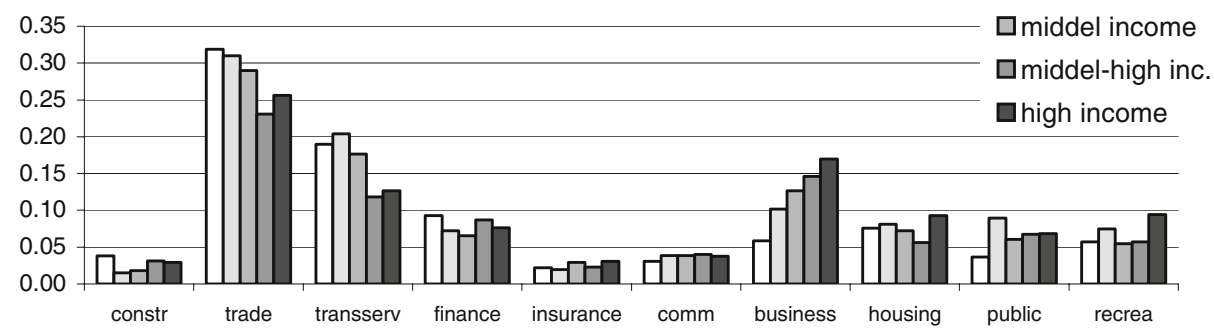

口low income

$\square$ middle-low inc.

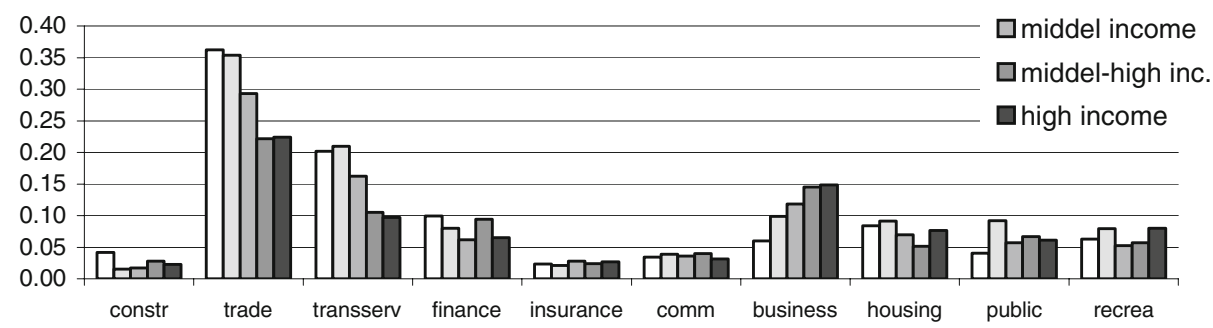

Fig. 3 Multiplier effects in different service activities by stage of development

multiplier effects are decreasing with rising per-capita income in most service categories apart from business services, housing and recreational services in these industries (lower panel of Fig. 3). In contrast, multiplier effects within service sectors grow stronger with increasing activity in technology intensive industries in more advanced countries (upper panel of Fig. 3). This rise is especially pronounced for business services. This again underlines the increasing importance of intermediate linkages through a higher degree of outsourcing of business service inputs and more use of overall service inputs in the highincome countries.

The ranking of service activities with the greatest total linkage multipliers $\omega$ from manufacturing demand differ between resource intensive, labor-intensive and technology intensive industries. While trade and repair is the sector receiving the strongest effects from 
increased production in all industries, the magnitude of the multiplier effect is highest in labor intensive industries. The multiplier coefficient for this service activity declines in the skill and technology intensity of the manufacturing sector, leading to the consequent output effects. We further observe a decline in multiplier coefficients for transportation services with increasing skill and technology intensity in manufacturing. On the other hand, business services coefficients are stronger the more sophisticated the manufacturing industry. All this suggests an increasing importance of business service activities along with economic development and the according structural shift towards more skill and technology intensive production.

As a next step we report OLS estimates for the stylized facts highlighted in Fig. 3. The regression equation is defined by equation (7):

$$
M_{i j k}=\alpha_{i j}+\beta 1_{i j} p c G D P_{k}+\beta 2_{i j} p c G D P_{k}^{2}+\varepsilon_{i j k}
$$

Where $M_{i j k}$ are the direct and indirect effects - as defined in equation (3)-generated in the respective service category $i$ as a result of an additional unit of output in each individual manufacturing industry $j$ (i.e. the multiplier effect of manufacturing in the service sector). Again, regressions are run separately for each industry in a cross-section over all 78 countries using a quadratic specification only when appropriate. The coefficients reported in Tables 7, 8, 9, 10, 11 are elasticities of the multiplier $M$ with respect to per-capita income levels. Here we look at the effects generated in individual service categories separately. For business services, we find a significant positive correlation of the direct and indirect effects generated by additional output in manufacturing and the stage of development. This holds true for all industries (see Table 7). In contrast to this clear result for business services, there are fewer clear patterns relating to stage of economic development for other producer relevant service categories. The negative effect in Table 8 for leather and clothing reveals that these two industries account for lower indirect and direct output effects

Table 7 Direct and indirect multiplier effects in business services

\begin{tabular}{|c|c|c|c|c|c|}
\hline & GDP & $t$-stat & $\mathrm{GDP}^{2}$ & $t$-stat & $R^{2}$ \\
\hline Food & 0.0396 & $4.02^{\mathrm{a}}$ & & & 0.13 \\
\hline Textiles & 0.0256 & $3.43^{\mathrm{a}}$ & & & 0.12 \\
\hline Clothing & 0.0161 & $1.93^{\mathrm{b}}$ & & & 0.04 \\
\hline Leather & 0.2142 & $1.98^{\mathrm{a}}$ & -0.0117 & $-1.82^{\mathrm{b}}$ & 0.06 \\
\hline Wood & 0.0218 & $2.38^{\mathrm{a}}$ & & & 0.05 \\
\hline Paper & 0.0452 & $4.56^{\mathrm{a}}$ & & & 0.20 \\
\hline Coke & 0.0151 & $2.15^{\mathrm{a}}$ & & & 0.04 \\
\hline Chemicals & 0.0384 & $4.48^{\mathrm{a}}$ & & & 0.20 \\
\hline Minerals & 0.0369 & $4.10^{\mathrm{a}}$ & & & 0.15 \\
\hline Metals & 0.0318 & $3.47^{\mathrm{a}}$ & & & 0.12 \\
\hline Machinery & 0.0411 & $5.21^{\mathrm{a}}$ & & & 0.26 \\
\hline Electrical equ. & 0.0353 & $4.91^{\mathrm{a}}$ & & & 0.20 \\
\hline Motor vehicles & 0.0347 & $4.71^{\mathrm{a}}$ & & & 0.19 \\
\hline Other transport equ. & 0.0298 & $3.65^{\mathrm{a}}$ & & & 0.11 \\
\hline Other manufacturing & 0.0294 & $3.60^{\mathrm{a}}$ & & & 0.11 \\
\hline
\end{tabular}

Dep. Var. is the multiplier coefficient in business services in resp. industry; robust std. errors

${ }^{a}$ Indicates significance at $1 \%$ level

${ }^{\mathrm{b}}$ Indicates significance at $5 \%$ level 
Table 8 Direct and indirect multiplier effects in communication services

\begin{tabular}{|c|c|c|c|c|c|}
\hline & GDP & $t$-stat & $\mathrm{GDP}^{2}$ & $t$-stat & $R^{2}$ \\
\hline Food & $-1.2 \mathrm{E}-04$ & -0.03 & & & 0.00 \\
\hline Textiles & $5.0 \mathrm{E}-06$ & 0.00 & & & 0.00 \\
\hline Clothing & $-5.3 \mathrm{E}-03$ & $-1.71^{\mathrm{b}}$ & & & 0.05 \\
\hline Leather & $-4.6 \mathrm{E}-03$ & $-1.68^{\mathrm{b}}$ & & & 0.05 \\
\hline Wood & $-3.0 \mathrm{E}-03$ & -0.93 & & & 0.01 \\
\hline Paper & 4.9E-03 & $1.83^{\mathrm{b}}$ & & & 0.05 \\
\hline Coke & 7.9E-02 & $2.40^{\mathrm{a}}$ & $-4.5 \mathrm{E}-03$ & $-2.32^{\mathrm{a}}$ & 0.05 \\
\hline Chemicals & $3.5 \mathrm{E}-03$ & 1.34 & & & 0.03 \\
\hline Minerals & $9.2 \mathrm{E}-04$ & 0.32 & & & 0.00 \\
\hline Metals & 4.4E-04 & 0.16 & & & 0.00 \\
\hline Machinery & $7.0 \mathrm{E}-03$ & $4.58^{\mathrm{a}}$ & & & 0.19 \\
\hline Electrical equ. & $4.6 \mathrm{E}-03$ & $3.08^{\mathrm{a}}$ & & & 0.09 \\
\hline Motor vehicles & 4.3E-03 & $2.50^{\mathrm{a}}$ & & & 0.05 \\
\hline Other transport equ. & $1.8 \mathrm{E}-03$ & 0.74 & & & 0.01 \\
\hline Other manufacturing & $-3.5 \mathrm{E}-04$ & -0.14 & & & 0.00 \\
\hline
\end{tabular}

Dep. Var. is the multiplier coefficient in communication services in resp. industry; robust std. errors

${ }^{a}$ Indicates significance at $1 \%$ level

${ }^{\mathrm{b}}$ Indicates significance at $5 \%$ level

in communication services in more advanced countries. On the other hand, the production of machinery, electrical equipment and motor vehicles generates increasingly strong multiplier effects in communication services in higher income countries. A similar finding arises for financial services, while here we often find a U-shaped relationship in less technology

Table 9 Direct and indirect multiplier effects in financial services

\begin{tabular}{|c|c|c|c|c|c|}
\hline & GDP & $t$-stat & $\mathrm{GDP}^{2}$ & $t$-stat & $R^{2}$ \\
\hline Food & $-2.8 \mathrm{E}-01$ & $-2.44^{\mathrm{a}}$ & $1.6 \mathrm{E}-02$ & $2.50^{\mathrm{a}}$ & 0.04 \\
\hline Textiles & $-1.1 \mathrm{E}-01$ & -1.40 & $6.4 \mathrm{E}-03$ & 1.36 & 0.01 \\
\hline Clothing & $-2.1 \mathrm{E}-01$ & $-1.87^{b}$ & $1.1 \mathrm{E}-02$ & $1.76^{\mathrm{b}}$ & 0.07 \\
\hline Leather & $-8.3 \mathrm{E}-02$ & -0.72 & 4.1E-03 & 0.64 & 0.03 \\
\hline Wood & $-1.7 \mathrm{E}-01$ & -1.42 & $9.3 \mathrm{E}-03$ & 1.37 & 0.04 \\
\hline Paper & $-2.9 \mathrm{E}-01$ & $-2.56^{\mathrm{a}}$ & $1.7 \mathrm{E}-02$ & $2.63^{\mathrm{a}}$ & 0.07 \\
\hline Coke & $9.4 \mathrm{E}-03$ & 0.13 & $-3.9 \mathrm{E}-04$ & -0.09 & 0.00 \\
\hline Chemicals & $-2.5 \mathrm{E}-01$ & $-2.20^{\mathrm{a}}$ & $1.4 \mathrm{E}-02$ & $2.30^{\mathrm{a}}$ & 0.08 \\
\hline Minerals & $-1.4 \mathrm{E}-01$ & -1.56 & 8.3E-03 & 1.61 & 0.02 \\
\hline Metals & $-2.1 \mathrm{E}-01$ & $-2.19^{\mathrm{a}}$ & $1.2 \mathrm{E}-02$ & $2.21^{\mathrm{a}}$ & 0.05 \\
\hline Machinery & $1.4 \mathrm{E}-02$ & $2.75^{\mathrm{a}}$ & & & 0.08 \\
\hline Electrical equ. & $1.0 \mathrm{E}-02$ & $2.12^{\mathrm{a}}$ & & & 0.05 \\
\hline Motor vehicles & 7.9E-03 & 0.13 & $-4.9 \mathrm{E}-05$ & -0.01 & 0.02 \\
\hline Other transport equ. & $-1.2 \mathrm{E}-01$ & -1.21 & $6.9 \mathrm{E}-03$ & 1.24 & 0.04 \\
\hline Other manufacturing & $-2.0 \mathrm{E}-01$ & $-1.97^{\mathrm{a}}$ & $1.1 \mathrm{E}-02$ & $2.03^{\mathrm{a}}$ & 0.03 \\
\hline
\end{tabular}

Dep. Var. is the multiplier coefficient in financial services in resp. industry; robust std. errors

${ }^{a}$ Indicates significance at $1 \%$ level

${ }^{\mathrm{b}}$ Indicates significance at 5\% level 
Table 10 Direct and indirect multiplier effects in insurance services

\begin{tabular}{|c|c|c|c|}
\hline & GDP & $t$-stat & $R^{2}$ \\
\hline Food & $3.8 \mathrm{E}-03$ & 1.15 & 0.02 \\
\hline Textiles & $2.5 \mathrm{E}-03$ & 1.23 & 0.01 \\
\hline Clothing & $-1.7 \mathrm{E}-03$ & -0.68 & 0.01 \\
\hline Leather & $-1.6 \mathrm{E}-03$ & -0.52 & 0.01 \\
\hline Wood & $3.0 \mathrm{E}-04$ & 0.10 & 0.00 \\
\hline Paper & $3.2 \mathrm{E}-03$ & 0.99 & 0.02 \\
\hline Coke & $2.6 \mathrm{E}-03$ & 1.54 & 0.02 \\
\hline Chemicals & $4.0 \mathrm{E}-03$ & 1.31 & 0.04 \\
\hline Minerals & $5.4 \mathrm{E}-03$ & $2.79^{\mathrm{a}}$ & 0.06 \\
\hline Metals & $3.1 \mathrm{E}-03$ & 1.24 & 0.02 \\
\hline Machinery & $5.9 \mathrm{E}-03$ & $3.69^{\mathrm{a}}$ & 0.12 \\
\hline Electrical equ. & $4.1 \mathrm{E}-03$ & $3.11^{\mathrm{a}}$ & 0.07 \\
\hline Motor vehicles & $5.1 \mathrm{E}-03$ & $3.42^{\mathrm{a}}$ & 0.09 \\
\hline Other transport equ. & $3.5 \mathrm{E}-03$ & $2.06^{\mathrm{a}}$ & 0.04 \\
\hline Other manufacturing & $2.0 \mathrm{E}-03$ & 0.64 & 0.01 \\
\hline
\end{tabular}

Dep. Var. is the multiplier coefficient in insurance services in resp. industry; robust std. errors

${ }^{a}$ Indicates significance at $1 \%$ level

intensive industries (Table 9). In insurance services, again the same industries account for higher multipliers in the higher income economies (Table 10). We also have a negative income correlation for multipliers in transportation (Table 11). Almost all manufacturing industries generate lower multipliers for transport services in the higher income economies. Only in the production of electrical equipment and motor vehicles and in the petroleum industry do we see first an increasing demand for transportation services in value terms,

Table 11 Direct and indirect multiplier effects in transportation services

\begin{tabular}{|c|c|c|c|c|c|}
\hline & GDP & $t$-stat & $\mathrm{GDP}^{2}$ & $t$-stat & $R^{2}$ \\
\hline Food & -0.043 & $-3.10^{\mathrm{a}}$ & & & 0.16 \\
\hline Textiles & -0.032 & $-2.17^{\mathrm{a}}$ & & & 0.11 \\
\hline Clothing & -0.055 & $-4.05^{\mathrm{a}}$ & & & 0.26 \\
\hline Leather & -0.053 & $-3.93^{\mathrm{a}}$ & & & 0.26 \\
\hline Wood & -0.051 & $-3.65^{\mathrm{a}}$ & & & 0.21 \\
\hline Paper & -0.016 & -1.37 & & & 0.03 \\
\hline Coke & 0.365 & $2.71^{\mathrm{a}}$ & -0.022 & $-2.78^{\mathrm{a}}$ & 0.11 \\
\hline Chemicals & -0.017 & -1.64 & & & 0.05 \\
\hline Minerals & -0.029 & $-2.14^{\mathrm{a}}$ & & & 0.08 \\
\hline Metals & -0.030 & $-2.91^{\mathrm{a}}$ & & & 0.12 \\
\hline Machinery & 0.002 & 0.29 & & & 0.00 \\
\hline Electrical equ. & 0.159 & $2.07^{\mathrm{a}}$ & -0.010 & $2.12^{\mathrm{a}}$ & 0.05 \\
\hline Motor vehicles & 0.277 & $2.78^{\mathrm{a}}$ & -0.016 & $-2.80^{\mathrm{a}}$ & 0.08 \\
\hline Other transport equ. & -0.020 & $-2.01^{\mathrm{a}}$ & & & 0.07 \\
\hline Other manufacturing & -0.039 & $-3.26^{\mathrm{a}}$ & & & 0.20 \\
\hline
\end{tabular}

Dep. Var. is the multiplier coefficient in transportation services in resp. industry; robust std. errors

${ }^{a}$ Indicates significance at $1 \%$ level 
which declines again at high stages of development. In our view this is likely to reflect greater overall efficiency in the transport systems of high income countries, rather than a structural shift in input demand.

\section{Services and trade}

From our discussion of intermediate linkages between services and manufacturing industries, we should expect trade in services, and the general openness of the producer service sectors, to play a role in the relative efficiency of manufacturing industries. Indeed, this is a basic point to be taken from the theoretical literature on trade in services. (Markusen 1989; Francois 1990b; van Marrewijk et al. 1997; Markusen et al. 2005). In this section, we examine the interaction between the evolution of producer service imports, on the one hand, and the relative success of various industries in overall manufacturing exports on the other. Because our panel data on services trade by sector are limited to the OECD, we work with our panel dataset of OECD exports, combined with the indirect service intensity coefficients $\mathbf{M}$ derived from our broader sample of social accounting data. We make the following observations based on our data:

Observation 5: In the cross-section, exports become increasingly producer (business) service intensive (in terms of combined direct and indirect linkages) with a rising level of development.

Observation 6: In the panel, inward FDI and trade openness in the service sector benefits the export competitiveness of manufacturing sectors with stronger service linkages, and hurts those with weaker upstream linkages to services.

Observation 7: In the panel, increased service sector openness (trade and FDI) yields a general equilibrium shift in value added and employment to service-input intensive manufacturing sectors.

Observation 8: From the panel, the combination of trade, output, and employment effects means that service sector openness has boosted the competitiveness of more technology and skill intensive industry in the OECD, at the expense of sectors like textiles and clothing.

\subsection{Direct and indirect exports}

From our development above of stylized facts linked to production, we expect greater service intensity to be linked to level of development. At the same time, from basic trade theory (Feenstra and Hanson 1996, 1999) we can also structure our expectations about how openness to intermediate services trade will impact on manufacturing. Indeed this is the guiding paradigm in the empirical off-shoring literature. We should expect those manufacturing sectors that are more producer service intensive (i.e. the higher technology sectors) to systematically benefit from increased openness, not only directly, but also indirectly in the competition with other sectors in the economy for resources. Indeed, in general equilibrium, we can expect more service intensive sectors to expand, and less service intensive sectors to contract.

We start here with the service intensity of total exports as measured by the direct and indirect effects generated by an additional dollar of exports in various other sectors of the economy. This involves the terms $\boldsymbol{\Phi}$ and $\Omega$ as defined in equations (4) and (5). Figure 4 
plots the combined direct and indirect multipliers $\omega$ for export effects for all sectors of the economy (except personal, cultural and recreational services, public services and housing, in which we are not interested here). In effect, this gives a fuller picture of the activity content of exports than simple export composition. Especially for the lowest income group, the most important contributor to exports is the agricultural sector. With rising per-capita income, the sector focus of exports is oriented increasingly toward industries such as chemicals, electrical equipment, machinery and especially business services. Within the services sector, again the relative importance of activities like trade and repair and transportation services declines with a rising income level.

Estimated OLS coefficients based on the data in Fig. 4 are reported in Table 12, based on equation (8).

$$
\omega_{i k}=\alpha_{i}+\beta 1_{i} p c G D P_{k}+\beta 2_{i} p c G D P_{k}^{2}+\varepsilon_{i k}
$$

where $\omega_{i j}$ is the additional activity (direct and indirect) in service sector $i$ in country $k$ as a result of one unit of additional merchandise exports of the economy. Here we run a regression for each service activity over all 78 countries in the sample. If we relate the indirect and direct activity composition of exports to per-capita income for our selected producer related service categories, we find again the strongest positive relationship in business services and further a weak (but not statistically significant) relationship in finance and insurance. Communication services show a weakly negative relationship and transportation services are characterized by less economic activity generated through additional exports in higher income countries. Thus again, it is the business services in which economic activity is rising significantly as a result of increased openness of the economy-proxied through exports. However, at very high levels of development, this trend is reversed and additional goods exports do not generate more activity in business services.

\subsection{Services imports and goods export composition}

Finally, we are interested in the impact of service sector imports on manufacturing performance. From Arnold et al. (2006) we have case-study evidence (based on the

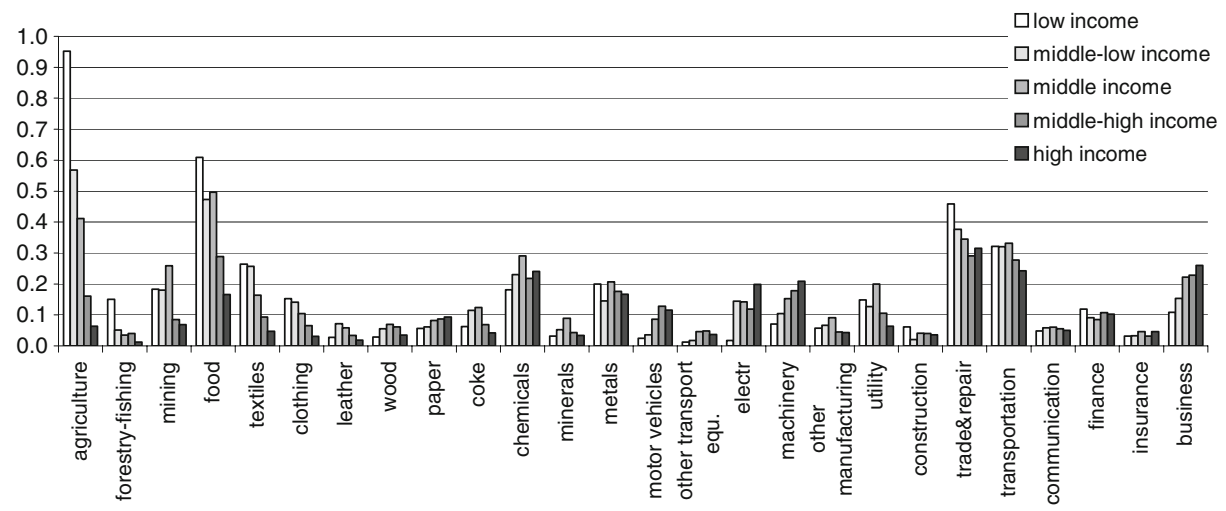

Fig. 4 Indirect and direct effects of exports on economic activity by sectors 
Table 12 Output effects of goods exports on service sector activity

\begin{tabular}{lrcccc}
\hline Service activity & \multicolumn{1}{l}{ GDP } & $t$-stat & \multicolumn{1}{c}{ GDP $^{2}$} & $t$-stat & $R^{2}$ \\
\hline Business & $9.12 \mathrm{E}-06$ & $4.39^{\mathrm{a}}$ & $-1.52 \mathrm{E}-10$ & $-4.87^{\mathrm{a}}$ & 0.095 \\
Communication & $9.10 \mathrm{E}-09$ & 0.01 & $-6.99 \mathrm{E}-12$ & -0.64 & 0.008 \\
Finance & $-2.56 \mathrm{E}-07$ & -0.12 & $2.01 \mathrm{E}-11$ & 0.48 & 0.007 \\
Insurance & $2.31 \mathrm{E}-07$ & 0.39 & $3.68 \mathrm{E}-12$ & 0.33 & 0.017 \\
Transportation & $-3.06 \mathrm{E}-06$ & $-2.13^{\mathrm{a}}$ & & & 0.045 \\
\hline
\end{tabular}

Dep. Var. is the total output effect of merchandise exports; robust std. errors

${ }^{a}$ Indicates significance at $1 \%$ level

experience of the Czech Republic) that service sector inward FDI can contribute to firm efficiency. Similarly, Javorcik (2004) identifies downstream benefits from upstream FDI using Lithuanian firm-level data. Here we look for similar evidence across the OECD and linked to services imports. We stress that the impact on firms should not be uniform, but should vary systematically by sector, so that in the macroeconomic data downstream impacts depend on the relative depth of intermediate linkages. In particular, from our analysis of social accounting-based indexes, we have a measure of the direct and indirect linkages between manufacturing activities and upstream service activities.

Tables 13, 14, 15 offer an assessment of linkage-driven effects, based on panel regression of OECD export data at the sector level for the industries defined in Appendix Table 16 for the time period 1994-2004. In evaluating the role played by service imports (i.e. off-shoring of services) we distinguish between different types of services, core business services, communication, financial and insurance services. Data for economy-wide service imports in each category (taken from the IMF) is interacted with the share of the respective service category used in each manufacturing industry. The latter is obtained from the SAMS (i.e. the $M_{i j}$ coefficient from Section 3). In this way we proxy for the total role of business service imports in the cost structure of various manufacturing industries. ${ }^{5}$ We further include total FDI inflows into the service sector as an alternative route for service inputs from abroad. All these variables are in logs. In addition, we control for implicit trade barriers as represented by domestic barriers to competition. For this we include indices of product market regulation from the OECD (Conway et al. 2005) for three broad dimensions: barriers to entrepreneurship, state control and barriers to foreign trade and investment. The empirical model is given in equation 9

$$
\begin{aligned}
\text { DepVar }_{i k t}= & \alpha_{i}+\beta 1_{i} \text { Mbusiness }_{i k t}+\beta 2_{i} \text { Mcomm }_{i k t}+\beta 3_{i} \text { Mfinance }_{i k t}+\beta 4 \text { Minsurance }_{i k t}+ \\
& +\beta 5_{i} \text { FDI }_{i k t}+\beta 6_{i} \text { Bentrepreneur }+\beta 7_{i} \text { Bstate }_{i k t}+\beta 8_{i} \text { Btrade }_{i k t}+\mu_{k}+\varepsilon_{i k t}
\end{aligned}
$$

where DepVar $i k t$ refers to either exports or value added or employment of manufacturing industry $i$ in year $t$ and country $k$. We are looking at the effect of trade in services on both, the domestic performance as well as exports of manufacturing industries. This should give a comprehensive picture of the full effects of economic integration within

\footnotetext{
${ }^{5}$ Our results are however robust to using economy wide imports of producer related services. Still, the interaction term gives a better approximation to the imports of services used by the respective manufacturing industry and thus a better fit.
} 
Table 13 Effects of off-shoring on manufacturing exports

\begin{tabular}{|c|c|c|c|}
\hline & \multicolumn{3}{|l|}{ Industry group } \\
\hline & Tech intensive & Labour intensive & Resource intensive \\
\hline \multirow[t]{2}{*}{ Imports of business services } & $0.2199^{\mathrm{a}}$ & $-0.2319^{\mathrm{b}}$ & -0.1637 \\
\hline & 1.68 & -1.96 & -1.26 \\
\hline \multirow[t]{2}{*}{ Imports of communication services } & -0.0819 & 0.2183 & 0.1875 \\
\hline & -0.36 & 0.91 & 0.99 \\
\hline \multirow[t]{2}{*}{ Imports of financial services } & 0.1618 & 0.0986 & -0.0365 \\
\hline & 1.10 & 0.67 & -0.3 \\
\hline \multirow[t]{2}{*}{ Imports of insurance services } & -0.1716 & -0.0266 & -0.1270 \\
\hline & -1.01 & -0.13 & -0.86 \\
\hline \multirow[t]{2}{*}{ Total FDI inflows } & -0.0016 & 0.0289 & 0.0095 \\
\hline & -0.04 & 0.54 & 0.22 \\
\hline \multirow[t]{2}{*}{ Barriers to entrepreneurship } & 0.0093 & 0.4122 & -0.0319 \\
\hline & 0.02 & 1.45 & -0.08 \\
\hline \multirow[t]{2}{*}{ State control } & -0.0806 & 0.2361 & 0.0244 \\
\hline & -0.35 & 1.05 & 0.13 \\
\hline \multirow[t]{2}{*}{ Barriers to trade and investment } & -0.1129 & 0.0643 & 0.1762 \\
\hline & -0.43 & 0.27 & 0.78 \\
\hline \multirow[t]{2}{*}{ Constant } & $-3.1994^{\mathrm{b}}$ & $-4.6532^{\mathrm{b}}$ & $-3.3768^{\mathrm{b}}$ \\
\hline & -4.29 & -5.08 & -4.67 \\
\hline Observations & 182 & 182 & 182 \\
\hline Groups & 23 & 23 & 23 \\
\hline Within $R^{2}$ & 28.45 & 19.56 & 2.19 \\
\hline Between $R^{2}$ & 37.40 & 41.29 & 36.60 \\
\hline Overall $R^{2}$ & 30.73 & 38.09 & 30.94 \\
\hline
\end{tabular}

2SLS regression results, instruments used: initial values, country dummies, value added of resp. industry group

a indicates significance at $5 \%$ level

${ }^{\mathrm{b}}$ Indicates significance at $1 \%$ level

service sectors on the manufacturing sector. The importance is here to distinguish between individual manufacturing industries. Based on general equilibrium considerations, we clearly expect to see different, even contradictory effects in qualitatively different industries, which may be hidden if we only look at the aggregate. Most of our control variables are highly correlated among themselves. In addition, there may also be a serious problem of endogeneity, especially between openness on the export side of the manufacturing sectors and their openness to service imports. Therefore we employ a 2SLS estimator. Because we work with share data, our dependent variable is put through a logistic transformation.

$$
\text { DepVar }_{i k t}=\log \left(\frac{\theta_{i k t}}{1-\theta_{i k t}}\right) \quad \text { where } \theta_{i k t}=X_{i k t} / \sum_{i} X_{i k t}
$$

where $X_{i k t}$ is one of the following: exports, value added or employment of industry $i$ in country $k$ in year $t$.

We cluster our 15 industries into the three groups of technology intensive, labor intensive and resource intensive. Regressions are run separately for the average over each group of 
Table 14 Effects of off-shoring on manufacturing value added

\begin{tabular}{|c|c|c|c|}
\hline & \multicolumn{3}{|l|}{ Industry group } \\
\hline & Tech intensive & Labour intensive & Resource intensive \\
\hline Imports of business services & $\begin{array}{l}0.1580^{\mathrm{a}} \\
(3.43)\end{array}$ & $\begin{array}{l}-0.2328^{\mathrm{a}} \\
(-3.22)\end{array}$ & $\begin{array}{l}-0.0047 \\
(-0.11)\end{array}$ \\
\hline Imports of communication services & $\begin{array}{l}0.1227 \\
(1.55)\end{array}$ & $\begin{array}{l}0.3692^{\mathrm{a}} \\
(3.1)\end{array}$ & $\begin{array}{l}0.0191 \\
(0.29)\end{array}$ \\
\hline Imports of financial services & $\begin{array}{l}0.0713 \\
(1.32)\end{array}$ & $\begin{array}{l}0.1152 \\
(1.33)\end{array}$ & $\begin{array}{l}-0.0820^{\mathrm{b}} \\
(-1.95)\end{array}$ \\
\hline Imports of insurance services & $\begin{array}{l}-0.1815^{\mathrm{a}} \\
(-2.66)\end{array}$ & $\begin{array}{l}-0.1924^{b} \\
(-1.86)\end{array}$ & $\begin{array}{l}0.0568 \\
(1.15)\end{array}$ \\
\hline Total FDI inflows & $\begin{array}{l}-0.0204^{b} \\
(-1.72)\end{array}$ & $\begin{array}{l}-0.0703^{\mathrm{a}} \\
(-3.36)\end{array}$ & $\begin{array}{l}-0.0107 \\
(-0.94)\end{array}$ \\
\hline Barriers to entrepreneurship & $\begin{array}{l}0.0313 \\
(0.62)\end{array}$ & $\begin{array}{l}0.1343^{\mathrm{b}} \\
(1.68)\end{array}$ & $\begin{array}{l}0.1140^{\mathrm{a}} \\
(2.59)\end{array}$ \\
\hline State control & $\begin{array}{l}-0.0746^{\mathrm{b}} \\
(-1.67)\end{array}$ & $\begin{array}{l}0.1311^{\mathrm{b}} \\
(1.78)\end{array}$ & $\begin{array}{l}-0.0454 \\
(-1.15)\end{array}$ \\
\hline Barriers to trade and investment & $\begin{array}{l}0.0588 \\
(1.34)\end{array}$ & $\begin{array}{l}-0.0002 \\
(0)\end{array}$ & $\begin{array}{l}0.0549 \\
(1.61)\end{array}$ \\
\hline Constant & $\begin{array}{l}-3.2654^{\mathrm{a}} \\
(-13.89)\end{array}$ & $\begin{array}{l}-3.0549^{\mathrm{a}} \\
(-8.45)\end{array}$ & $\begin{array}{l}-2.9601^{\mathrm{a}} \\
(-15.63)\end{array}$ \\
\hline Chi-squared & 55.34 & 66.17 & 37.04 \\
\hline within $R^{2}$ & 0.0847 & 0.2081 & 0.1594 \\
\hline Between $R^{2}$ & 0.4580 & 0.2133 & 0.0341 \\
\hline Overall $R^{2}$ & 0.3588 & 0.2021 & 0.0228 \\
\hline Observations & 182 & 182 & 182 \\
\hline
\end{tabular}

2SLS regression results, instruments used: initial values, country dummies, value added of resp. industry group

${ }^{\text {a }}$ Indicates significance at $1 \%$ level

${ }^{\mathrm{b}}$ Indicates significance at $5 \%$ level

industries and the results are reported in Tables 13, 14, 15. Tables 17, 18, 19, 20, 21, 22, 23, 24, 25, in the Appendix contain further regression results for individual industries.

What emerges from the regressions is that imports of business services are an important determinant of the pattern of manufacturing exports in the most advanced industries. While no significant effects from service imports on total manufacturing exports on average can be detected, there are clear positive effects in the most technology intensive industries (here defined as chemicals, electric equipment, machinery and motor vehicles). Again, as was to be expected, it is the imports of core business services that play a role here, while the coefficients on communication, insurance and financial services do not turn out to be significant for the group as such. The results differ somewhat for each individual industry (see Appendix Table 17). On the other hand, a negative effect from increased business service imports emerges when we are restricting our attention to labor intensive industries only. This holds true in particular for the textiles, clothing and leather industries. Finally, no effects are found for resource intensive industries. This points to the more advanced industries being vertically integrated, not only nationally but also internationally through the off-shoring of business services. Indeed, the results in Table 13 support the notion that off-shoring of business services does actually promote the competitiveness of the most skill and technology intensive industries.

We find similar effects for domestic value added and employment in manufacturing. We report these results in Tables 14 and 15. Value added is again enhanced through greater 
Table 15 Effects of off-shoring on manufacturing employment

\begin{tabular}{|c|c|c|c|}
\hline & \multicolumn{3}{|l|}{ Industry group } \\
\hline & Tech intensive & Labour intensive & Resource intensive \\
\hline \multirow[t]{2}{*}{ Imports of business services } & $0.1484^{\mathrm{a}}$ & -0.1705 & 0.0226 \\
\hline & $(2.51)$ & $(-1.52)$ & $(0.6)$ \\
\hline \multirow[t]{2}{*}{ Imports of communication services } & 0.0030 & 0.2229 & -0.0024 \\
\hline & $(0.04)$ & $(1.39)$ & $(-0.04)$ \\
\hline \multirow[t]{2}{*}{ Imports of financial services } & 0.0166 & 0.1373 & -0.0479 \\
\hline & $(0.24)$ & $(0.97)$ & $(-1.32)$ \\
\hline \multirow[t]{2}{*}{ Imports of insurance services } & -0.0732 & -0.2321 & 0.0270 \\
\hline & $(-0.89)$ & $(-1.5)$ & $(0.62)$ \\
\hline \multirow[t]{2}{*}{ Total FDI inflows } & -0.0041 & -0.0335 & 0.0002 \\
\hline & $(-0.63)$ & $(-1.46)$ & $(0.04)$ \\
\hline \multirow[t]{2}{*}{ Barriers to entrepreneurship } & 0.0368 & 0.0094 & 0.0035 \\
\hline & $(0.89)$ & $(0.11)$ & $(0.15)$ \\
\hline \multirow[t]{2}{*}{ State control } & $-0.0607^{\mathrm{a}}$ & $0.1220^{\mathrm{b}}$ & 0.0186 \\
\hline & $(-2.16)$ & $(1.86)$ & $(0.89)$ \\
\hline \multirow[t]{2}{*}{ Barriers to trade and investment } & 0.0303 & 0.0383 & -0.0047 \\
\hline & $(0.65)$ & $(0.43)$ & $(-0.22)$ \\
\hline \multirow[t]{2}{*}{ Constant } & $-3.2772^{b}$ & $-2.8969^{\mathrm{a}}$ & $-3.2611^{\mathrm{a}}$ \\
\hline & $(-12.63)$ & $(-5.46)$ & $(-21.8)$ \\
\hline Chi-squared & 79.95 & 48.33 & 9.49 \\
\hline Within $R^{2}$ & 0.2403 & 0.1843 & 0.0675 \\
\hline Between $R^{2}$ & 0.4571 & 0.3002 & 0.0001 \\
\hline Overall $R^{2}$ & 0.3547 & 0.2695 & 0.0001 \\
\hline Observations & 182 & 182 & 182 \\
\hline
\end{tabular}

2SLS regression results, instruments used: initial values, country dummies, value added of resp. industry group

${ }^{\text {a }}$ Indicates significance at $1 \%$ level

${ }^{\mathrm{b}}$ Indicates significance at $5 \%$ level

openness to imports of business services for technology intensive industries, while labor intensive industries mostly experience a contraction when the economy opens up to business services from abroad. The negative coefficient on total FDI inflows may be explained by the fact that economies with higher inward FDI are potentially more service based (since the majority of FDI is often in service sectors) and derive less value added from manufacturing production in general. The negative sign of the coefficient on insurance service imports for technology is puzzling. Finally, we look at the effects of service sector openness on employment. We would expect to see fewer and weaker effects on employment than on value added, since most countries in the sample are characterized by rather rigid labor markets and thus not immediately responsive to changes in the economic environment. Indeed we find fewer significant coefficients when regressing service sector openness on manufacturing employment. The positive effect from imported business services in high tech industries remains, while no negative effects are seen for labor intensive industries. For individual industries we do see however negative employment effects for textiles, clothing and leather.

Hence, we observe not only positive output effects, but also positive employment effects from off-shoring of services in the most skill and technology intensive industries. These results are fully consistent with general equilibrium linkages across sectors through intermediates as well as factor markets. Because of general equilibrium effects, positive 
effects in service intensive sectors are off-set by negative output and employment effects in labor intensive production activities, especially so in the textile and clothing sector. Thus, it is important to take a holistic look at the issue of service sector openness for an economy. The effects of opening up to trade in business services differ greatly between individual manufacturing activities with an ambiguous effect on the whole economy.

\section{Summary}

A marked aspect of the globalization process has been increased international integration not only of goods sectors, but also of service sectors. This is reflected not only in trade agreements and negotiations, but also in trade flows and FDI. Yet, compared to goods, our understanding of the possible impact of services trade is limited. (See Hoekman 2000 and Mattoo 2000.)

In this paper we have combined panel regressions on trade in goods and services with cross-country evidence on the structure of production, including intermediate linkages, to both quantify the importance of services as embodied in goods exports, and also the possible impact of service sector liberalization on the performance of goods sectors. We find that while goods dominate direct trade data, services are often the most important activities contributing to final exports. The incongruity between official trade data and our result follows from the importance of non-traded service inputs in the production of traded manufactures. In addition we find that, again because of their role as inputs, increased import penetration by producer services has a positive effect on the skill and technology mix of exports, with greater openness in producer service sectors implying better export performance by skill and technology intensive industries. Protecting intermediate service sectors places manufacturing sectors (especially high wage manufacturing sectors) at a competitive disadvantage. Overall, our results point to service sector openness as a potentially positive factor in the evolution of efficiency in the most technology intensive manufacturing industries. This result, which is based on our work with panel data on trade and a cross-section of social accounts data (SAMs), complements (and also supports) the results coming from the current literature based on individual country/case studies.

Open Access This article is distributed under the terms of the Creative Commons Attribution Noncommercial License which permits any noncommercial use, distribution, and reproduction in any medium, provided the original author(s) and source are credited.

\section{Appendix}

Table 16 Sector and country aggregations

Manufacturing sectors

Technology intensive Labor intensive

Resource intensive

Other

Service sectors

Producer services

Other
Chemicals, machinery, electrical equ., motor vehicles

Food, textiles, clothing, leather, other transport equ.

Wood, paper, coke, minerals, metals

Other manufacturing

Transportation, financial, insurance, communication, business, Construction, trade, housing, public, personal-cultural and recreational services, utilities 
Table 16 (continued)

Manufacturing sectors

\begin{tabular}{ll}
\hline Countries: & \\
Low income & BGD, KHM, MDG, MOZ, MWI, NGA, TZA, UGA, ZMB \\
Middle-low income & ALB, BOL, CHN, ECU, IDN, IND, LKA, MAR, PAK, PER, PHL, VNM, ZWE \\
Middle income & BGR, BRA, BWA, COL, IRN, LTU, LVA, MEX, MKD, MYS, ROM, \\
& RUS, THA, TUN, TUR, URY, VEN \\
Middle-high income & ARG, CHL, CYP, CZE, ESP, EST, GRC, HRV, HUN, KOR, MLT, \\
& MUS, NZL, POL, PRT, SVK, SVN, ZAF \\
High income & AUS, AUT, BEL, CAN, CHE, DEU, DNK, FIN, FRA, GBR, HKG, \\
& IRL, ITA, JPN, LUX, NLD, NOR, SGP, SWE, TWN, USA
\end{tabular}

Table 17 Effects of off-shoring on technology intensive industries' exports

\begin{tabular}{lllll}
\hline & Chemicals & Electric equipment & Machinery & Motor vehicles \\
\hline Imports of business services & $0.1800^{\mathrm{a}}$ & $0.2192^{\mathrm{b}}$ & $0.2064^{\mathrm{b}}$ & 0.2006 \\
& $(1.86)$ & $(3.30)$ & $(2.18)$ & $(1.45)$ \\
Imports of communication services & -0.1170 & -0.1260 & 0.1012 & -0.0179 \\
& $(-0.82)$ & $(-0.95)$ & $(0.98)$ & $(-0.08)$ \\
Imports of financial services & -0.0952 & $0.1900^{\mathrm{b}}$ & 0.1646 & $0.2712^{\mathrm{b}}$ \\
& $(-0.87)$ & $(2.16)$ & $(1.36)$ & $(2.02)$ \\
Imports of insurance services & $0.2080^{\mathrm{b}}$ & $-0.2096^{\mathrm{b}}$ & $-0.2843^{\mathrm{b}}$ & $-0.4077^{\mathrm{b}}$ \\
& $(2.20)$ & $(-1.96)$ & $(-2.32)$ & $(-2.84)$ \\
Total FDI inflows & 0.0228 & 0.0206 & -0.0279 & 0.0097 \\
Barriers to entrepreneurship & $(1.28)$ & $(0.69)$ & $(-1.61)$ & $(0.32)$ \\
State control & -0.0990 & $0.1982^{\mathrm{a}}$ & 0.0396 & 0.0811 \\
Barriers to trade and investment & $(-1.35)$ & $(1.71)$ & $(0.45)$ & $(0.60)$ \\
Constant & -0.0188 & $-0.2041^{\mathrm{b}}$ & 0.0281 & $-0.2101^{\mathrm{a}}$ \\
Observations & $(-0.33)$ & $(-2.06)$ & $(0.40)$ & $(-1.84)$ \\
Groups & 0.0453 & -0.1437 & 0.0327 & 0.0278 \\
Within $R^{2}$ & $(0.62)$ & $(-1.59)$ & $(0.36)$ & $(0.24)$ \\
Between $R^{2}$ & $-2.8780^{\mathrm{b}}$ & $-3.6377^{\mathrm{b}}$ & $-3.2548^{\mathrm{b}}$ & $-3.4938^{\mathrm{b}}$ \\
Overall $R^{2}$ & $(-5.97)$ & $(-8.94)$ & $(-6.45)$ & $(-5.35)$ \\
\hline
\end{tabular}

2SLS regression results, instruments used: initial values, country dummies, value added of resp. industry group

${ }^{a}$ Indicates significance at 5\% level

${ }^{\mathrm{b}}$ Indicates significance at $1 \%$ level

Table 18 Effects of off-shoring on technology intensive industries' value added

\begin{tabular}{lllll}
\hline & Chemicals & Electric equipment & Machinery & Motor vehicles \\
\hline Imports of business services & $0.1767^{\mathrm{a}}$ & $0.1678^{\mathrm{a}}$ & $0.2033^{\mathrm{a}}$ & -0.0609 \\
& $(3.59)$ & $(4.74)$ & $(3.82)$ & $(-0.88)$ \\
Imports of communication services & $-0.1491^{\mathrm{a}}$ & -0.0714 & $0.1583^{\mathrm{a}}$ & $0.4245^{\mathrm{a}}$
\end{tabular}


Table 18 (continued)

\begin{tabular}{lllll}
\hline & Chemicals & Electric equipment & Machinery & Motor vehicles \\
\hline & $(-2.05)$ & $(-0.95)$ & $(2.2)$ & $(3.46)$ \\
Imports of financial services & -0.0761 & $0.1181^{\mathrm{a}}$ & -0.0665 & $0.1675^{\mathrm{a}}$ \\
& $(-1.46)$ & $(2.76)$ & $(-0.99)$ & $(2.55)$ \\
Imports of insurance services & $0.2713^{\mathrm{a}}$ & $-0.1596^{\mathrm{a}}$ & $-0.1562^{\mathrm{a}}$ & $-0.4002^{\mathrm{a}}$ \\
& $(4.73)$ & $(-2.7)$ & $(-2)$ & $(-5.1)$ \\
Total FDI inflows & 0.0093 & -0.0285 & $-0.0555^{\mathrm{a}}$ & 0.0547 \\
& $(0.58)$ & $(-0.82)$ & $(-3.7)$ & $(1.56)$ \\
Barriers to entrepreneurship & -0.0317 & -0.0426 & $0.1126^{\mathrm{b}}$ & 0.2065 \\
State control & $(-0.52)$ & $(-0.37)$ & $(1.73)$ & $(1.5)$ \\
Barriers to trade and investment & -0.0329 & -0.0523 & 0.0014 & $-0.3718^{\mathrm{a}}$ \\
& $(-0.58)$ & $(-0.77)$ & $(0.02)$ & $(-3.7)$ \\
Constant & $0.1145^{\mathrm{a}}$ & 0.0012 & 0.0200 & $0.2038^{\mathrm{a}}$ \\
Chi-squared & $(2.34)$ & $(0.02)$ & $(0.34)$ & $(2.15)$ \\
Within $R^{2}$ & $-2.8050^{\mathrm{a}}$ & $-2.6475^{\mathrm{a}}$ & $-3.5617^{\mathrm{a}}$ & $-3.3405^{\mathrm{a}}$ \\
Between $R^{2}$ & $(-10.33)$ & $(-8.68)$ & $(-11.68)$ & $(-7.95)$ \\
Overall $R^{2}$ & 77.12 & 38.03 & 43.34 & 63.24 \\
Observations & 0.1957 & 0.0310 & 0.0564 & 0.0416 \\
\hline
\end{tabular}

2SLS regression results, instruments used: initial values, country dummies, value added of resp. industry group ${ }^{\text {a }}$ Indicates significance at $1 \%$ level

${ }^{\mathrm{b}}$ Indicates significance at $5 \%$ level

Table 19 Effects of off-shoring on technology intensive industries' employment

\begin{tabular}{lllll}
\hline & Chemicals & Electric equipment & Machinery & Motor vehicles \\
\hline Imports of business services & $0.0823^{\mathrm{a}}$ & $0.1808^{\mathrm{a}}$ & $0.1995^{\mathrm{b}}$ & 0.0230 \\
& $(2.11)$ & $(4.62)$ & $(1.78)$ & $(0.24)$ \\
Imports of communication services & 0.0264 & -0.1317 & -0.0975 & $0.4294^{\mathrm{a}}$ \\
& $(0.46)$ & $(-1.79)^{\mathrm{b}}$ & $(-1.03)$ & $(2.61)$ \\
Imports of financial services & -0.0167 & 0.0150 & -0.1268 & $0.1718^{\mathrm{b}}$ \\
& $(-0.38)$ & $(0.29)$ & $(-0.88)$ & $(1.83)$ \\
Imports of insurance services & 0.0191 & -0.0358 & 0.0400 & $-0.3490^{\mathrm{a}}$ \\
& $(0.49)$ & $(-0.57)$ & $(0.31)$ & $(-3.42)$ \\
Total FDI inflows & -0.0079 & 0.0091 & 0.0039 & -0.0310 \\
Barriers to entrepreneurship & $(-1.06)$ & $(0.87)$ & $(0.29)$ & $(-1.34)$ \\
State control & 0.0074 & 0.0265 & -0.0104 & $0.1996^{\mathrm{a}}$ \\
Barriers to trade and investment & $(0.24)$ & $(0.57)$ & $(-0.12)$ & $(1.97)$ \\
Constant & 0.0192 & $-0.1409^{\mathrm{a}}$ & 0.0209 & $-0.1426^{\mathrm{b}}$ \\
Chi-squared & $(0.79)$ & $(-3.56)$ & $(0.39)$ & $(-1.65)$ \\
Within $R^{2}$ & $\left(-0.0512^{\mathrm{b}}\right.$ & 0.0633 & 0.0379 & 0.0351 \\
& $(-1.72)$ & $(1.49)$ & $(0.38)$ & $(0.42)$ \\
& $-2.7410^{\mathrm{a}}$ & $-2.8931^{\mathrm{a}}$ & $-3.2591^{\mathrm{a}}$ & $-3.6769^{\mathrm{a}}$
\end{tabular}


Table 19 (continued)

\begin{tabular}{lllll}
\hline & Chemicals & Electric equipment & Machinery & Motor vehicles \\
\hline Between $R^{2}$ & 0.3964 & 0.2934 & 0.4275 & 0.3994 \\
Overall $R^{2}$ & 0.4093 & 0.2444 & 0.3994 & 0.2691 \\
Observations & 182 & 182 & 182 & 182
\end{tabular}

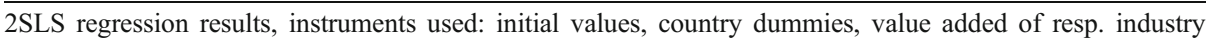
group

${ }^{\text {a }}$ Indicates significance at $1 \%$ level

${ }^{\mathrm{b}}$ Indicates significance at $5 \%$ level

Table 20 Effects of off-shoring on labor intensive industries' exports

\begin{tabular}{|c|c|c|c|c|c|}
\hline & Textiles & Clothing & Leather & Food & Other transport equ. \\
\hline \multirow[t]{2}{*}{ Imports of business services } & $-0.2398^{\mathrm{a}}$ & $-0.3545^{\mathrm{a}}$ & $-0.3157^{\mathrm{b}}$ & -0.2210 & $0.1617^{\mathrm{a}}$ \\
\hline & -2.07 & -2.71 & -1.80 & -0.91 & 2.44 \\
\hline \multirow[t]{2}{*}{ Imports of communication services } & $0.4755^{\mathrm{a}}$ & $0.3532^{\mathrm{b}}$ & $0.5171^{\mathrm{a}}$ & 0.1822 & 0.1391 \\
\hline & 2.82 & 1.69 & 1.99 & 0.42 & 1.08 \\
\hline \multirow[t]{2}{*}{ Imports of financial services } & 0.1067 & -0.1861 & -0.0449 & -0.0568 & 0.0312 \\
\hline & 0.61 & -1.29 & -0.25 & -0.22 & 0.54 \\
\hline \multirow[t]{2}{*}{ Imports of insurance services } & -0.2449 & 0.0137 & $-0.3889^{\mathrm{b}}$ & 0.2246 & -0.0188 \\
\hline & -1.19 & 0.07 & -1.81 & 0.67 & -0.23 \\
\hline \multirow[t]{2}{*}{ Total FDI inflows } & $-0.0556^{\mathrm{b}}$ & 0.0050 & -0.0381 & -0.0492 & 0.0011 \\
\hline & -1.83 & 0.16 & -1.04 & -1.11 & 0.04 \\
\hline \multirow[t]{2}{*}{ Barriers to entrepreneurship } & 0.0381 & -0.0616 & -0.0338 & -0.0004 & 0.1175 \\
\hline & 0.34 & -0.51 & -0.24 & 0.00 & 1.08 \\
\hline \multirow[t]{2}{*}{ State control } & $0.4283^{\mathrm{a}}$ & $0.6461^{\mathrm{a}}$ & $0.4038^{\mathrm{a}}$ & 0.1697 & $-0.2075^{\mathrm{a}}$ \\
\hline & 4.30 & 5.82 & 3.09 & 1.44 & -2.36 \\
\hline \multirow[t]{2}{*}{ Barriers to trade and investment } & -0.1713 & $-0.2486^{\mathrm{a}}$ & 0.0002 & -0.0373 & $0.3073^{\mathrm{a}}$ \\
\hline & -1.55 & -2.24 & 0.00 & -0.20 & 3.81 \\
\hline \multirow[t]{2}{*}{ Constant } & $-3.4368^{\mathrm{a}}$ & $-3.6929^{\mathrm{a}}$ & $-4.1782^{\mathrm{a}}$ & -1.8342 & $-4.8493^{\mathrm{a}}$ \\
\hline & -6.06 & -5.84 & -5.54 & -1.62 & -12.83 \\
\hline Observations & 182 & 182 & 182 & 182 & 182 \\
\hline Groups & 23 & 23 & 23 & 23 & 23 \\
\hline Within $R^{2}$ & 12.34 & 26.53 & 23.81 & 9.35 & 0.26 \\
\hline Between $R^{2}$ & 16.88 & 29.76 & 10.36 & 20.5 & 38.4 \\
\hline Overall $R^{2}$ & 19.65 & 31.31 & 13.7 & 12.26 & 36.65 \\
\hline
\end{tabular}

2SLS regression results, instruments used: initial values, country dummies, value added of resp. industry group

${ }^{\text {a }}$ Indicates significance at $1 \%$ level

${ }^{\mathrm{b}}$ Indicates significance at $5 \%$ level

Table 21 Effects of off-shoring on labor intensive industries' value added

\begin{tabular}{llllll}
\hline & Textiles & Clothing & Leather & Food & Other transport equ. \\
\hline Imports of business services & $-0.2721^{\mathrm{a}}$ & $-0.2682^{\mathrm{a}}$ & $-0.2182^{\mathrm{a}}$ & -0.0625 & $-0.2247^{\mathrm{a}}$ \\
& $(-4.11)$ & $(-3.81)$ & $(-2.15)$ & $(-1.49)$ & $(-4.48)$ \\
Imports of communication services & $0.4711^{\mathrm{a}}$ & $0.2184^{\mathrm{b}}$ & 0.1493 & -0.0066 & $0.2267^{\mathrm{a}}$ \\
& $(4.38)$ & $(1.95)$ & $(1.01)$ & $(-0.08)$ & $(2.45)$
\end{tabular}


Table 21 (continued)

\begin{tabular}{llllll}
\hline & Textiles & Clothing & Leather & Food & Other transport equ. \\
\hline Imports of financial services & 0.0298 & -0.0132 & $0.1785^{\mathrm{b}}$ & -0.0305 & 0.0226 \\
& $(0.31)$ & $(-0.16)$ & $(1.72)$ & $(-0.69)$ & $(0.57)$ \\
Imports of insurance services & -0.1521 & 0.1255 & $-0.2767^{\mathrm{a}}$ & $0.1861^{\mathrm{a}}$ & -0.0096 \\
& $(-1.34)$ & $(1.22)$ & $(-2.3)$ & $(3.19)$ & $(-0.16)$ \\
Total FDI inflows & $-0.0676^{\mathrm{a}}$ & $-0.0646^{\mathrm{a}}$ & -0.0409 & $-0.0469^{\mathrm{a}}$ & 0.0465 \\
& $(-2.81)$ & $(-2.6)$ & $(-1.33)$ & $(-2.76)$ & $(1.42)$ \\
Barriers to entrepreneurship & $0.2621^{\mathrm{a}}$ & $0.2162^{\mathrm{a}}$ & 0.0430 & -0.0404 & 0.0942 \\
& $(2.83)$ & $(2.19)$ & $(0.35)$ & $(-0.65)$ & $(0.76)$ \\
State control & $0.1649^{\mathrm{b}}$ & 0.1513 & $0.2327^{\mathrm{a}}$ & $0.1061^{\mathrm{a}}$ & -0.0212 \\
& $(1.94)$ & $(1.63)$ & $(2.15)$ & $(1.88)$ & $(-0.29)$ \\
Barriers to trade and investment & -0.0392 & -0.0440 & $0.1731^{\mathrm{b}}$ & -0.0007 & -0.0021 \\
& $(-0.5)$ & $(-0.53)$ & $(1.79)$ & $(-0.01)$ & $(-0.02)$ \\
Constant & $-3.1309^{\mathrm{a}}$ & $-3.1935^{\mathrm{a}}$ & $-5.0142^{\mathrm{a}}$ & $-1.4992^{\mathrm{a}}$ & $-3.1769^{\mathrm{a}}$ \\
Chi-squared & $(-8.88)$ & $(-8.33)$ & $(-10.36)$ & $(-6.15)$ & $(-9.77)$ \\
Within $R^{2}$ & 78.11 & 75.41 & 87.82 & 51.63 & 29.04 \\
Between $R^{2}$ & 0.2643 & 0.3302 & 0.3744 & 0.0578 & 0.0260 \\
Overall $R^{2}$ & 0.1474 & 0.1667 & 0.2297 & 0.3600 & 0.2098 \\
Observations & 0.1609 & 0.1125 & 0.2567 & 0.1915 & 0.1469 \\
\hline
\end{tabular}

2SLS regression results, instruments used: initial values, country dummies, value added of resp. industry group

${ }^{a}$ Indicates significance at $1 \%$ level

${ }^{\mathrm{b}}$ Indicates significance at 5\% level

Table 22 Effects of off-shoring on labor intensive industries' employment

\begin{tabular}{llllll}
\hline & Textiles & Clothing & Leather & Food & Other transport equ. \\
\hline Imports of business services & $-0.2013^{\mathrm{a}}$ & $-0.3105^{\mathrm{a}}$ & $-0.3040^{\mathrm{a}}$ & -0.0633 & -0.0739 \\
& $(-2.23)$ & $(-3.54)$ & $(-1.65)$ & $(-0.96)$ & $(-1.01)$ \\
& $0.3651^{\mathrm{a}}$ & 0.2266 & 0.2561 & -0.0237 & $0.2764^{\mathrm{a}}$ \\
Imports of communication services & $(2.79)$ & $(1.61)$ & $(0.93)$ & $(-0.19)$ & $(1.96)$ \\
& 0.1058 & -0.0373 & 0.0662 & -0.0271 & -0.0044 \\
Imports of financial services & $(0.77)$ & $(-0.37)$ & $(0.35)$ & $(-0.39)$ & $(-0.07)$ \\
& -0.2144 & 0.0493 & $-0.3995^{\mathrm{b}}$ & 0.0927 & -0.1118 \\
Imports of insurance services & $(-1.33)$ & $(0.37)$ & $(-1.75)$ & $(1.03)$ & $(-1.31)$ \\
& $-0.0572^{\mathrm{a}}$ & -0.0317 & -0.0138 & -0.0012 & -0.0258 \\
Total FDI inflows & $(-2.45)$ & $(-1.36)$ & $(-0.41)$ & $(-0.1)$ & $(-1.51)$ \\
Barriers to entrepreneurship & 0.1048 & $0.2659^{\mathrm{a}}$ & -0.0075 & -0.0503 & 0.0092 \\
State control & $(1.23)$ & $(2.91)$ & $(-0.06)$ & $(-1.08)$ & $(0.12)$ \\
& 0.1017 & $0.1551^{\mathrm{b}}$ & $0.2846^{\mathrm{a}}$ & 0.0194 & 0.0765 \\
Barriers to trade and investment & $(1.35)$ & $(1.79)$ & $(2.58)$ & $(0.53)$ & $(1.18)$ \\
Constant & 0.0390 & -0.1351 & -0.0065 & -0.0287 & 0.0251 \\
Chi-squared & $-2.7238^{\mathrm{a}}$ & $-2.2888^{\mathrm{a}}$ & $-3.7129^{\mathrm{a}}$ & $-1.3968^{\mathrm{a}}$ & $-3.4886^{\mathrm{a}}$ \\
Within $R^{2}$ & $(-6.19)$ & $(-5.23)$ & $(-4.86)$ & $(-4.53)$ & $(-9.55)$ \\
& 51.22 & 74.69 & 61.20 & 10.07 & 12.86 \\
& 0.1471 & 0.3306 & 0.2445 & 0.0341 & 0.0132
\end{tabular}


Table 22 (continued)

\begin{tabular}{llllll}
\hline & Textiles & Clothing & Leather & Food & Other transport equ. \\
\hline Between $R^{2}$ & 0.1201 & 0.1073 & 0.1952 & 0.2644 & 0.0445 \\
Overall $R^{2}$ & 0.1046 & 0.0730 & 0.1966 & 0.1704 & 0.0284 \\
Observations & 182 & 182 & 182 & 182 & 182 \\
\hline
\end{tabular}

2SLS regression results, instruments used: initial values, country dummies, value added of resp. industry group

${ }^{a}$ Indicates significance at $1 \%$ level

${ }^{\mathrm{b}}$ Indicates significance at $5 \%$ level

Table 23 Effects of off-shoring on resource intensive industries' exports

\begin{tabular}{lllllc}
\hline & Coke & Minerals & Metals & Paper & Wood \\
\hline Imports of business services & -0.2281 & -0.0745 & -0.0120 & 0.0699 & -0.2775 \\
& -1.15 & -0.5 & -0.12 & 0.29 & -0.75 \\
Imports of communication services & $0.5615^{\mathrm{a}}$ & -0.1871 & -0.1518 & -0.1949 & 0.3910 \\
& 2.33 & -0.81 & -1.13 & -0.54 & 0.73 \\
Imports of financial services & $-0.2643^{\mathrm{b}}$ & 0.1826 & -0.1305 & -0.2768 & 0.1491 \\
& -1.7 & 0.97 & -1.03 & -1.26 & 0.42 \\
Imports of insurance services & $-0.2544^{\mathrm{b}}$ & -0.0794 & 0.0331 & 0.2269 & -0.3994 \\
& -1.72 & -0.36 & 0.22 & 1.1 & -0.88 \\
Total FDI inflows & -0.0795 & 0.0013 & 0.0109 & 0.0401 & -0.0178 \\
Barriers to entrepreneurship & -0.92 & 0.05 & 0.69 & 1.07 & -0.31 \\
State control & $-0.6948^{\mathrm{a}}$ & -0.1749 & 0.0112 & 0.1668 & 0.0201 \\
& -2.05 & -1.61 & 0.14 & 1.33 & 0.12 \\
Barriers to trade and investment & -0.3932 & $0.1441^{\mathrm{b}}$ & -0.0312 & 0.0428 & 0.1402 \\
& -1.36 & 1.82 & -0.51 & 0.42 & 0.93 \\
Constant & 0.2810 & 0.0624 & 0.0809 & -0.2450 & -0.0217 \\
Observations & 1.16 & 0.55 & 0.99 & -2.0 & -0.11 \\
Groups & -1.6813 & $-3.9813^{\mathrm{a}}$ & $-2.0436^{\mathrm{a}}$ & $-3.4588^{\mathrm{a}}$ & $-3.2008^{\mathrm{a}}$ \\
Within $R^{2}$ & -1.41 & -6.04 & -4.69 & -3.51 & -2.05 \\
Between $R^{2}$ & 182 & 182 & 182 & 182 & 182 \\
Overall $R^{2}$ & 23 & 23 & 23 & 23 & 23 \\
& 4.86 & 11.83 & 18.05 & 7.52 & 0.26
\end{tabular}

2SLS regression results, instruments used: initial values, country dummies, value added of resp. industry group

${ }^{a}$ Indicates significance at $1 \%$ level

${ }^{\mathrm{b}}$ Indicates significance at 5\% level

Table 24 Effects of off-shoring on resource intensive industries' value added

\begin{tabular}{|c|c|c|c|c|c|}
\hline & Coke & Minerals & Metals & Paper & Wood \\
\hline Imports of business services & $\begin{array}{l}-0.0770 \\
(-1.44)\end{array}$ & $\begin{array}{l}-0.0771^{\mathrm{a}} \\
(-2.06)\end{array}$ & $\begin{array}{l}0.1842^{\mathrm{a}} \\
(2.74)\end{array}$ & $\begin{array}{l}0.0362 \\
(0.49)\end{array}$ & $\begin{array}{l}-0.1884^{\mathrm{a}} \\
(-2.4)\end{array}$ \\
\hline Imports of communication services & $\begin{array}{l}0.0838 \\
(1.33)\end{array}$ & $\begin{array}{l}0.0840 \\
(1.32)\end{array}$ & $\begin{array}{l}0.0608 \\
(0.63)\end{array}$ & $\begin{array}{l}-0.0664 \\
(-0.62)\end{array}$ & $\begin{array}{l}0.2570^{\mathrm{a}} \\
(2.11)\end{array}$ \\
\hline
\end{tabular}


Table 24 (continued)

\begin{tabular}{llllll}
\hline & Coke & Minerals & Metals & Paper & Wood \\
\hline Imports of financial services & -0.0485 & 0.0047 & -0.0427 & $-0.1384^{\mathrm{b}}$ & $-0.1528^{\mathrm{b}}$ \\
& $(-1.15)$ & $(0.11)$ & $(-0.49)$ & $(-1.9)$ & $(-1.87)$ \\
Imports of insurance services & $0.1391^{\mathrm{a}}$ & $-0.1025^{\mathrm{b}}$ & $-0.1813^{\mathrm{b}}$ & $0.2253^{\mathrm{a}}$ & 0.0923 \\
& $(3.6)$ & $(-1.87)$ & $(-1.74)$ & $(2.88)$ & $(0.93)$ \\
Total FDI inflows & 0.0208 & -0.0007 & $-0.0418^{\mathrm{a}}$ & 0.0047 & -0.0279 \\
& $(0.56)$ & $(-0.04)$ & $(-3.1)$ & $(0.29)$ & $(-1.42)$ \\
Barriers to entrepreneurship & $0.4257^{\mathrm{a}}$ & 0.0892 & 0.0510 & $0.1962^{\mathrm{a}}$ & $0.2869^{\mathrm{a}}$ \\
& $(2.81)$ & $(1.45)$ & $(0.79)$ & $(3.14)$ & $(3.68)$ \\
State control & $-0.1552^{\mathrm{b}}$ & 0.0433 & -0.0161 & -0.0172 & -0.0625 \\
& $(-1.75)$ & $(0.84)$ & $(-0.31)$ & $(-0.3)$ & $(-0.88)$ \\
Barriers to trade and investment & $0.2565^{\mathrm{a}}$ & -0.0689 & $0.1200^{\mathrm{a}}$ & $-0.1553^{\mathrm{a}}$ & -0.1016 \\
Constant & $(2.85)$ & $(-1.55)$ & $(2.02)$ & $(-3.04)$ & $(-1.51)$ \\
& $-4.4701^{\mathrm{a}}$ & $-2.8506^{\mathrm{a}}$ & $-2.7602^{\mathrm{a}}$ & $-2.2913^{\mathrm{a}}$ & $-2.7460^{\mathrm{a}}$ \\
Chi-squared & $(-11.55)$ & $(-13.5)$ & $(-8.7)$ & $(-7.26)$ & $(-7.58)$ \\
Within $R^{2}$ & 39.72 & 17.30 & 47.30 & 27.77 & 26.25 \\
Between $R^{2}$ & 0.1224 & 0.0627 & 0.1499 & 0.0889 & 0.0832 \\
Overall $R^{2}$ & 0.2234 & 0.1290 & 0.1471 & 0.0046 & 0.0062 \\
Observations & 0.1777 & 0.1664 & 0.1807 & 0.0128 & 0.0294 \\
\hline
\end{tabular}

2SLS regression results, instruments used: initial values, country dummies, value added of resp. industry group

${ }^{a}$ Indicates significance at $1 \%$ level

${ }^{\mathrm{b}}$ Indicates significance at 5\% level

Table 25 Effects of off-shoring on resource intensive industries' employment

\begin{tabular}{llllll}
\hline & Coke & Minerals & Metals & Paper & Wood \\
\hline Imports of business services & -0.0154 & -0.0412 & $0.1372^{\mathrm{a}}$ & 0.0401 & -0.1353 \\
& $(-0.3)$ & $(-0.57)$ & $(2.41)$ & $(0.49)$ & $(-1.44)$ \\
Imports of communication services & $0.1898^{\mathrm{a}}$ & 0.1006 & 0.0711 & 0.0790 & 0.0787 \\
& $(3.04)$ & $(0.88)$ & $(0.91)$ & $(0.66)$ & $(0.57)$ \\
Imports of financial services & -0.0616 & 0.0287 & 0.0109 & -0.0660 & -0.0782 \\
& $(-1.54)$ & $(0.32)$ & $(0.15)$ & $(-0.87)$ & $(-0.86)$ \\
Imports of insurance services & $-0.0832^{\mathrm{a}}$ & -0.1123 & -0.1419 & 0.0940 & 0.0721 \\
& $(-2.16)$ & $(-1.07)$ & $(-1.62)$ & $(1.26)$ & $(0.62)$ \\
Total FDI inflows & -0.0279 & -0.0100 & -0.0033 & -0.0102 & 0.0063 \\
Barriers to entrepreneurship & $(-1.52)$ & $(-0.74)$ & $(-0.37)$ & $(-0.75)$ & $(0.41)$ \\
State control & 0.0321 & -0.0167 & -0.0305 & $0.0975^{\mathrm{a}}$ & $0.0997^{\mathrm{a}}$ \\
& $(0.43)$ & $(-0.29)$ & $(-0.64)$ & $(2.02)$ & $(1.97)$ \\
Barriers to trade and investment & $-0.1245^{\mathrm{b}}$ & 0.0482 & 0.0372 & 0.0540 & 0.0258 \\
& $(-1.83)$ & $(1.09)$ & $(1.07)$ & $(1.29)$ & $(0.58)$ \\
Constant & $0.2264^{\mathrm{a}}$ & -0.0198 & 0.0458 & $-0.1247^{\mathrm{a}}$ & $-0.1387^{\mathrm{a}}$ \\
Chi-squared & $(4.15)$ & $(-0.35)$ & $(0.96)$ & $(-2.81)$ & $(-2.47)$ \\
Within $R^{2}$ & $-4.8050^{\mathrm{a}}$ & $-2.9705^{\mathrm{a}}$ & $-2.7968^{\mathrm{a}}$ & $-2.7772^{\mathrm{a}}$ & $-2.6498^{\mathrm{a}}$ \\
& $(-16.62)$ & $(-9.19)$ & $(-11.03)$ & $(-8.32)$ & $(-6.61)$ \\
& 42.95 & 3.00 & 33.94 & 32.90 & 13.54 \\
& 0.0871 & 0.0446 & 0.0732 & 0.0287 & 0.0328
\end{tabular}


Table 25 (continued)

\begin{tabular}{llllll}
\hline & Coke & Minerals & Metals & Paper & Wood \\
\hline Between $R^{2}$ & 0.3311 & 0.0524 & 0.2418 & 0.2338 & 0.0443 \\
Overall $R^{2}$ & 0.2812 & 0.0863 & 0.2788 & 0.2333 & 0.0687 \\
Observations & 182 & 182 & 182 & 182 & 182
\end{tabular}

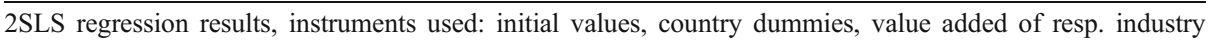
group

${ }^{\text {a }}$ Indicates significance at $1 \%$ level

${ }^{\mathrm{b}}$ Indicates significance at $5 \%$ level

\section{References}

Amiti, M. and Wei, S.-J., "Service Offshoring, Productivity, and Employment: Evidence from the United States," International Monetary Fund working paper WP/05/238, 2005.

Arnold, J., Javorcik, B.S., and Mattoo, A., "The Productivity Effects of Services Liberalization: Evidence from the Czech Republic." World Bank working paper, 2006.

Baumol, W.J., Blackman, S.A.B., and Wolff, E.N., "Unbalanced Growth Revisited: Asymptotic Stagnancy and New Evidence," American Economic Review, vol. 75(4), pp. 806-817, 1985.

Bhagwati, J.N., "Why Are Services Cheaper in the Poor Countries?” Economic Journal, vol. 94, pp. 279-286, 1984 a.

Bhagwati, J.N., "Splintering and Disembodiment of Services and Developing Nations," The World Economy, (June), pp. 133-144, 1984b.

Bloningen, B.A., A review of the empirical literature on FDI determinants. NBER Working Papers No. 11299, Cambridge, MA, 2005.

Bloningen, B.A., Flynn, J.E., and Reinert, K.A., "Sector-Focused General Equilibrium Modeling," in Francois, J.F. and Reinert, E.K.A. (eds.), Applied Methods for Trade Policy Analysis. A Handbook. Cambridge (Cambridge University Press), 1997.

Clark, C., The Conditions of Economic Progress. London (Macmillan), 1940.

Dimaranan, B.V. editor, Global Trade, Assistance, and Production: The GTAP 6 Data Base, Centre for Global Trade Analysis, Purdue University, 2006.

Feenstra, R. and Hanson, G., "Globalization, Outsourcing, and Wage Inequality," American Economic Review, vol. 86, pp. 240-245, 1996.

Feenstra, R. and Hanson, G., "The Impact of Outsourcing and High-Technology Capital on Wages: Estimates for the United States, 1979-1990," The Quarterly Journal of Economics, vol. 114-3, pp. 907-940, 1999.

Feenstra, R., and Hanson, R., "Global Production Sharing and Rising Inequality: A Survey of Trade and Wages," in Choi, E.K., and Harrigan, J. (Eds.), Handbook of International Trade, Blackwell, 2003.

Francois, J.F., "Producer Services, Scale, and the Division of Labor," Oxford Economic Papers, vol. 42(4), pp. 715-729, 1990a.

Francois, J.F., "Increasing Returns Due to Specialization, Monopolistic Competition, and Trade in Producer Services." Canadian Journal of Economics, 1990b.

Francois, J., Reinert, K., "The Role of Services in the Structure of Production and Trade: Stylized Facts from a Cross-Country Analysis.” Asia-Pacific Economic Review, 1996.

Francois, J., Grier, K., and Nelson, D., "Globalization, Roundaboutness, and Relative Wages," Centre for Economic Policy Research discussion paper 4406, 2004.

Hoekman, B., "The New Round of Services Negotiations: Identifying Priorities and Options," Federal Reserve Bank of Saint Louis, vol. 82, pp. 31-47, 2000.

Hoekman, B., "Liberalizing Trade in Services: A Survey," World Bank discussion paper, October, 2006.

Hoekman, B. and Primo Braga, C.A., "Protection and Trade in Services: A Survey," Open Economies Review, vol. 8, no. 3pp. 285-308, 1997.

Hunter, L. and Markusen, J.R., "Per-Capita Income as a Determinant of Trade," in Feenstra, R. (ed.), Empirical Methods for International Economics. Cambridge, Massachusetts (MIT Press), pp. 89-109, 1989.

Javorcik, B., "Does Foreign Direct Investment Increase the Productivity of Domestic Firms? In Search of Spillovers Through Backward Linkages," The American Economic Review, vol. 94, no. 3pp. 605-627, 2004. 
Katouzian, M.A., "The Development of the Service Sector: A New Approach,” Oxford Economic Papers, vol. 22(3), pp. 362-282, 1970.

Markusen, J.R., "Trade in Producer Services and Other Specialized Intermediate Inputs," The American Economic Review, vol. 79, pp. 85-95, 1989.

Markusen, J.R., "Modeling the Offshoring of White-Collar Services: From Comparative Advantage to the New Theories of Trade and FDI," paper prepared for the Brookings Forum, Offshoring White-Collar Work: The Issues and Implications, 2005.

Markusen, J.R. and Venables, A.J., "The Role of Multinational Firms in the Wage-Gap Debate," Review of International Economics, vol. 5(4), pp. 435-451, 1997.

Markusen, J., Rutherford, T., and Tarr, D., "Trade and Direct Investment in Producer Services and the Domestic Market for Expertise," Canadian Journal of Economics, vol. 38(3), pp. 758-777, 2005.

Mattoo, A., "Developing Countries in the New Round of GATS Negotiations: Towards a Pro-active Role," The World Economy, pp. 471-90, 2000 (April).

Panagariya, A., "A Theoretical Explanation of Some Stylized Facts of Economic Growth," Quarterly Journal of Economics, vol. 103, pp. 509-526, 1988.

Park, S.-H., "Linkages between Industry and Services and their Implications for Urban Employment Generation in Developing Countries," Journal of Development Economics, vol. 30 (April)pp. 359-379, 1989.

Park, S.-H. and Chan, K.S., "A Cross-Country Input-Output Analysis of Intersectoral Relationships between Manufacturing and Services and their Employment Implications," World Development, vol. 17, no. 2pp. 199-212, 1989.

Reinert, K.A. and Roland-Holst, D.W., "Structural Change in the United States: Social Accounting Estimates for 1982-1988," Empirical Economics, vol. 19(3), pp. 429-449, 1994.

Reinert, K.A. and Roland-Holst, D.W., "Social Accounting Matrices," in Francois, J.F. and Reinert, K.A. (eds.), Applied Methods for Trade Policy Analysis. Cambridge (Cambridge University Press), 1997.

Robinson, S., "Multisectoral Models," in Chenery, H.B. and Srinivasan, T.N. (eds.), Handbook of Development Economics. Amsterdam (North Holland), pp. 885-947, 1989.

Uno, K., Measurement of Services in an Input-Output Framework, North Holland, Amsterdam, 1989.

van Marrewijk, C., Stibora, J., de Vaal, A., and Viaene, J.-M., "Producer Services, Comparative Advantage, and International Trade Patterns," Journal of International Economics, vol. 42, pp. 195-220, 1997.

Yeaple, S.R., "Offshoring, Foreign Direct Investment, and the Structure of U.S. Trade," Journal of the European Economic Association, vol. 4(2-3), pp. 602-611, 2006. 